\title{
Article
}

\section{Is Information Diffusion a Threat to Market Power for Financial Access? Insights from the African Banking Industry}

Asongu, Simplice, Batuo, Enowbi, Nwachukwu, Jacinta Chikaodi and Tchamyou, Vanessa

Available at http://clok.uclan.ac.uk/24985/

Asongu, Simplice, Batuo, Enowbi, Nwachukwu, Jacinta Chikaodi ORCID: 00000003-2987-9242 and Tchamyou, Vanessa (2018) Is Information Diffusion a Threat to Market Power for Financial Access? Insights from the African Banking Industry. Journal of Multinational Financial Management, 45 . pp. 88104. ISSN 1042-444X

It is advisable to refer to the publisher's version if you intend to cite from the work. http://dx.doi.org/10.1016/j.mulfin.2018.04.005

For more information about UCLan's research in this area go to http://www.uclan.ac.uk/researchgroups/ and search for < name of research Group>.

For information about Research generally at UCLan please go to http://www.uclan.ac.uk/research/

All outputs in CLoK are protected by Intellectual Property Rights law, including Copyright law. Copyright, IPR and Moral Rights for the works on this site are retained by the individual authors and/or other copyright owners. Terms and conditions for use of this material are defined in the policies page. 

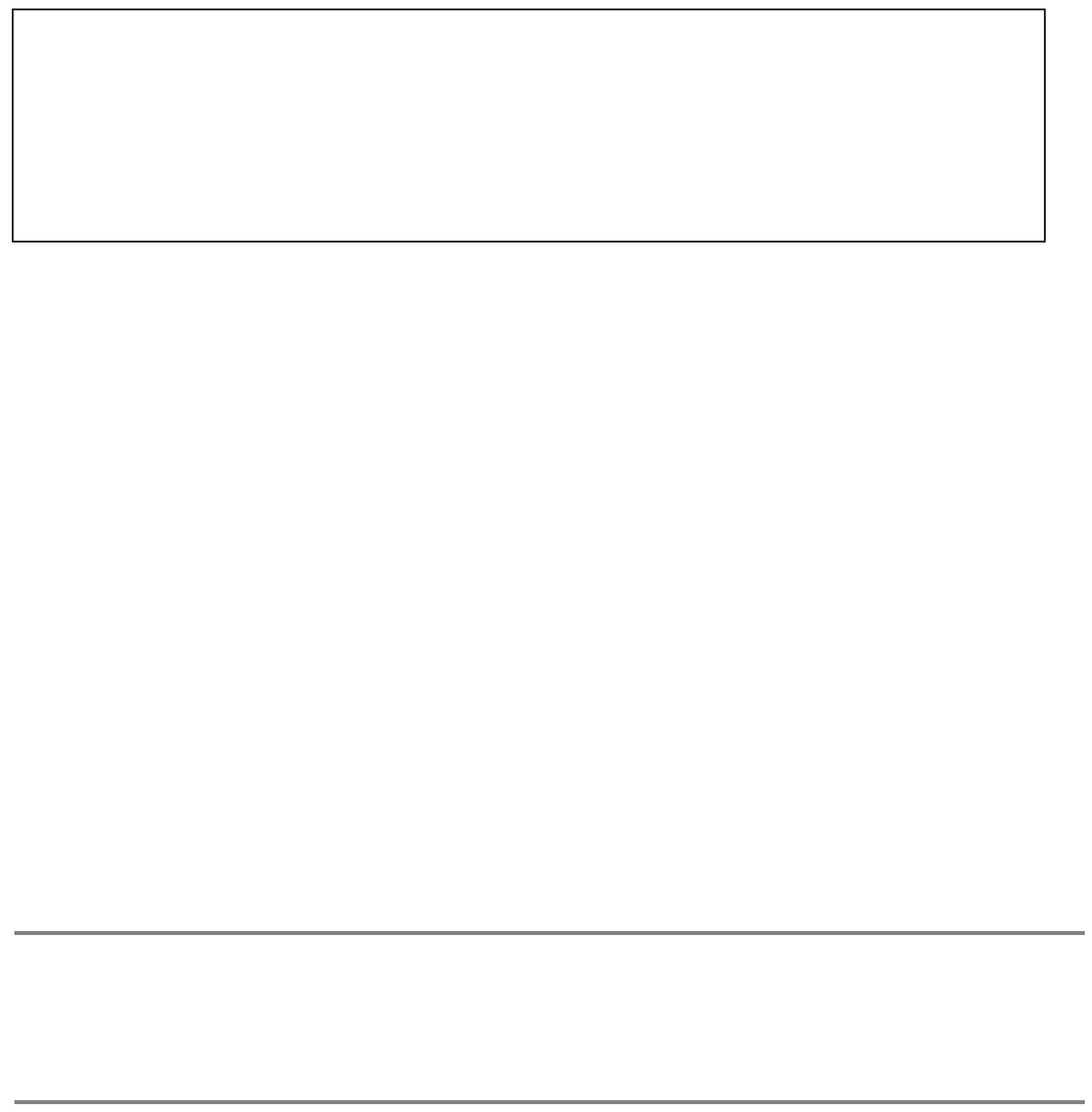



\section{Accepted Manuscript}

Title: Is information diffusion a threat to market power for financial access? Insights from the African banking industry

Authors: Simplice Asongu, Enowbi Batuo, Jacinta

Nwachukwu, Vanessa Tchamyou

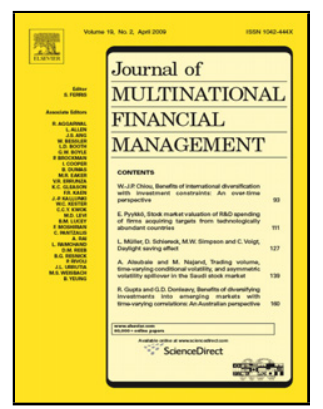

PII:

S1042-444X(17)30305-5

DOI: https://doi.org/10.1016/j.mulfin.2018.04.005

Reference: MULFIN 556

To appear in: J. of Multi. Fin. Manag.

Received date: $\quad$ 6-12-2017

Revised date: $\quad 18-4-2018$

Accepted date: $\quad$ 22-4-2018

Please cite this article as: Asongu S, Batuo E, Nwachukwu J, Tchamyou V, Is information diffusion a threat to market power for financial access? Insights from the African banking industry, Journal of Multinational Financial Management (2010), https://doi.org/10.1016/j.mulfin.2018.04.005

This is a PDF file of an unedited manuscript that has been accepted for publication. As a service to our customers we are providing this early version of the manuscript. The manuscript will undergo copyediting, typesetting, and review of the resulting proof before it is published in its final form. Please note that during the production process errors may be discovered which could affect the content, and all legal disclaimers that apply to the journal pertain. 
Is information diffusion a threat to market power for financial access? Insights from the

\title{
African banking industry
}

\section{Simplice Asongu ${ }^{a}$, Enowbi Batuo ${ }^{\text {b }}$, Jacinta Nwachukwu ${ }^{c}$ \& Vanessa Tchamyou ${ }^{d}$}

${ }^{\text {a }}$ Development Finance Centre,

Graduate School of Business,

University of Cape Town, Cape Town, South Africa

E-mails: asongusimplice@yahoo.com / asongus@afridev.org

Tel : 0032473613172

${ }^{\mathrm{b}}$ University of Westminster,

Department of Economics and Quantitative Methods.

Email: enowbi71@yahoo.it

${ }^{\mathrm{c} S c h o o l ~ o f ~ E c o n o m i c s, ~ F i n a n c e ~ a n d ~ A c c o u n t i n g, ~}$

Faculty of Business and Law,

Coventry University Priory Street, Coventry, CV1 5FB, UK

Email: jacinta.nwachukwu@ coventry.ac.uk

${ }^{\mathrm{d}}$ Faculty of Applied Economics,

University of Antwerp, Antwerp Belgium

E-mails: simenvanessa@yahoo.com / simenvanessa@afridev.org

\section{Highlights}

This study assesses how information diffusion dampens the adverse effect of market power.

It further investigates how such modulation affects loan price and loan quantity.

The focus is on a panel of 162 banks from 39 African countries.

Policy thresholds at which the modulation can improve financial access are provided.

\begin{abstract}
This study assesses how information diffusion dampens the adverse effect of market power on the price and quantity of loans provided by a panel of 162 banks from 39 African countries for the period 2001-2011. First, from the Generalised Method of Moments results, a mobile phone penetration rate of 54.29 , rising to 57 per 100 people are predicted to neutralise the
\end{abstract}


adverse effect of market power on the average loan price and quantity respectively. Second, from the Quantile Regressions, mobile phone penetration rates of 56.20, 52.04 and 42.76 per 100 people is needed to nullify the negative effect of market power on loan quantity at the $10^{\text {th }}$ decile, $25^{\text {th }}$ quartile and $90^{\text {th }}$ decile respectively. Third, a considerably lower internet penetration rate of 9.49 per 100 people is required to counteract the negative impact of market power on loan quantity at the $90^{\text {th }}$ decile. Policy implications are discussed.

JEL Classification: G20; G29; L96; O40; O55

Keywords: Financial access; Market power; Information asymmetry; ICT; Africa

\section{Introduction}

There are four principal motivations for examining whether information diffusion threatens market power in order to enhance financial access in the African banking industry, notably: the high potential for information and communication technology (ICT) penetration in Africa; surplus liquidity and market power issues in banks of the continent; the relevance of information diffusion in reducing market power for financial access and gaps in the literature. The four motivations are substantiated in chronological order.

First, compared to the rest of the world, there is a higher potential for penetration of mechanisms of information technology in Africa. Consistent with recent literature, whereas high-end economies in North America, Europe and Asia are witnessing saturation points in the growth of ICT, there is yet considerable room for ICT penetration in Africa (Penard et al., 2012; Asongu, 2018; Afutu-Kotey et al., 2017; Bongomin et al., 2018; Gosavi, 2017). This implies that policy can leverage on such penetration potential to address development concerns, inter alia limited financial access. 
Second, banks in Africa are characterised by issues of surplus liquidity (Saxegaard, 2006; Fouda, 2009; Asongu, 2014), which is paradoxical in the light of the experience of households and corporations with limited access to credit (Bartels et al., 2009; Tuomi, 2011; Darley, 2012). Some of the documented determinants of surplus liquidity include: lack of borrowing collateral, absence of bank accounts, lack of credit histories, absence of good infrastructure that may oblige bank branches in remote areas to hold cash in excess of statutory limits and the abuse of market power by big banks (Tchamyou \& Asongu, 2017).

Third, information diffusion can reduce market power or limit data privileges and informational rents previously enjoyed by big banks. Big banks can use such advantages to set the price of loans above marginal costs in order to increase their profit margins. This intuition is consistent with Bergemanny et al. (2015) who have argued that the interaction of market power and information is crucial in comprehending the distribution of quantities and prices that result in economic equilibrium.

Fourth, recent literature has suggested that financial institutions in the African banking industry may be abusing their market power in order to limit access to finance (Boateng et al., 2018). In other words, such financial intermediaries may be more concerned with enjoying a 'quiet life'1 instead of increasing financial access (Asongu et al., 2016a). Unfortunately, Africa has not been given the scholarly attention it deserves. This is essentially because, as the continent with the most severe financial access issues, studies devoted to assessing the influence of market power in the African banking industry are sparse (see Table 1).

This inquiry therefore aims to complement existing literature and policy challenges by merging the four strands above in assessing how information diffusion dampens the

\footnotetext{
${ }^{1}$ The Quiet Life Hypothesis (QLH) postulates that financial institutions with high market power would invest less to enhance financial access. According to the assumption, instead of using their favourable market position to enhance intermediation efficiency, such banks tend to exploit such 'market power' to increase their gains or enjoy a 'quiet life' (Coccorese \& Pellecchia, 2010).
} 
potentially negative effect of market power on financial access in the African banking industry. The results are linked to have policies which should enhance access to mobilised deposits in the banking sector for both households and small businesses. This leads to increased consumption, investment, productivity, employment and ultimately economic prosperity.

In the light of the above, the research question this study aims to answer is the following: is information diffusion a threat to market power for financial access? As summarised in Table 1 and Section 2, the extant literature has not addressed the research gap this research question seeks to answer. Hence, our study departs from the discussed literature in Section 2 by assessing how the potential for ICT penetration (covered in the first strand of the introduction) can be leveraged to mitigate market power (discussed in the third strand) in order to increase financial access (covered in the second strand) and extend the literature on market power in the banking industry (highlighted in the fourth strand). In what follows, we complement the motivation of the study by outlining the research framework (data and methodological insights), summarizing the key findings and contextualizing the contribution of key findings in the light of extant literature.

In order to assess whether information diffusion is a threat to market power for financial access in a panel of 162 banks from 39 African countries for the period 2001-2011, we first derive the Lerner index or market power by estimating a translog cost function. Then, we employ three simultaneity-robust empirical strategies, namely: (i) Two-Stage Least Squares (2SLS) to control for simultaneity, (ii) Generalised Method of Moments (GMM) to account for simultaneity, the unobserved heterogeneity and persistence in financial access (i.e. in loan price and loan quantity) and (iii) Instrumental Variable Quantile Regressions (QR) to control for simultaneity and existing levels of financial access. 
Three main findings are established. First, from the GMM results, a mobile phone penetration rate of 54.29 , rising to 57 per 100 people are predicted to neutralise the adverse effect of market power on the average loan price and quantity respectively. Second, from the $\mathrm{QR}$, mobile phone penetration rates of $56.20,52.04$ and 42.76 per 100 people is needed to nullify the negative effect of market power on loan quantity at the $10^{\text {th }}$ decile, $25^{\text {th }}$ quartile and $90^{\text {th }}$ decile respectively. Third, a considerably lower internet penetration rate of 9.49 per 100 people is required to counteract the negative impact of market power on loan quantity at the $90^{\text {th }}$ decile.

The above findings contribute to the scholarly literature in at least three ways. First, by employing ICT channels, our study complements a recent strand of African financial development literature which has exclusively focused on information sharing offices (such as private credit bureaus and public credit registries) as information sharing mechanisms in the diffusion of knowledge for the reduction of information asymmetry between lenders and borrowers in the banking industry, notably: Kusi et al. (2017) who have concluded that the sharing of information reduces bank credit risk, Kusi and Opoku- Mensah (2018) who have established that such information sharing mitigates the cost of funding while Muaza and Alagidede (2017) who have concluded that, the financial access benefits from information sharing are more apparent in English common law countries compared to their French civil law counterparts.

Second, the findings also enlighten another strand of recent African banking literature which has postulated that the ineffectiveness of information sharing offices in Africa may be due to the abuse of market power by large financial institutions (Triki \& Gajigo, 2014; Asongu et al., 2016a). It is important to note that the concept of market power is not directly engaged by this strand of literature. Hence, by directly engaging the concept of market power in this study, the findings provide insights into whether ICT mechanisms (which are complementary to 
information sharing offices) are reducing information asymmetry associated with market power in order to increase financial access in the African banking industry.

Third, some of the insignificant findings on the relevance of ICT in modulating the effect of market power on financial access may imply that market power in the African banking industry may be so strong that its effect on financial access cannot easily be modulated by ICT of low penetration. Hence, the insignificant findings should not be observed in the light of publication bias or the file drawer concern in social sciences, where compared to strong results that are more likely to be published, insignificant and null findings are not published and discarded (Rosenberg, 2005; Franco et al., 2014).

The rest of the investigation is structured as follows. Section 2 discusses linkages between information flow, market power and financial access. The data and methodology are covered in Section 3 while Section 4 presents the empirical results. Section 5 concludes with future research directions.

\section{Information Diffusion, Market Power and Financial Access}

\subsection{Information diffusion and theoretical underpinnings}

By playing a fundamental role in information diffusion, ICT improves governance and reduces the abuse of government power by facilitating transparency, openness and the freeflow of information between various institutions and departments in the government (Hellstrom, 20008). For example, in accordance with the narrative, mobile telephony enables: (i) the free flow of information between citizens and authorities and (ii) direct involvement of citizens in processes of governance. In summary, advantages of a mobile phone can also be reaped in the banking industry because by making financial institutions more connected and up-to-date, it encourages customers to be more participative in the process of lending. Such could decrease the informational rents previously enjoyed by big banks. 
Ultimately, information flow has the potential for decreasing the asymmetry between lenders and borrowers. On the one hand, ex-ante of lending, information distribution can mitigate the adverse selection of banks (especially big banks) by enabling them to be better informed about borrowers' creditworthiness. On the other, ex-post of lending, the potential for moral hazard can be substantially limited because the circulation of information improves transparency and accountability. Such should prevent borrowers from concealing activities for which they borrowed funds as well as the earning there-from.

In the light of the above, the role of ICT in reducing market power in the banking industry is not so different from how ICT decreases the abuse of power by the ruling elite. On the potential role of ICT in decreasing market power, Snow (2009, pp. 337-339) has documented some theoretical underpinnings. According to Snow, the historic dearth of ICT provided those with power and authority with privileged information and communication facilities that substantially constrained transparency and promoted corruption.

Conversely, the rapid diffusion of information (by means of ICT) has shrunk the secrecy barriers and rents by inter alia: altering cost-benefit calculations and increasing oversight. These propositions are founded on the intuition that information monopoly among the elite in government or banking industry is an avenue for the abuse of power. Hence, the decentralisation of information through ICT reduces opportunities for those in government and banking circles to take advantage of their privileged positions. The theoretical foundations are broadly in line with the growing number of papers on the interconnections between ICT, governance and the abuse of power on the one hand (Boulianne, 2009; Diamond, 2010; Grossman et al., 2014) and on the other, the evolving stream of literature on the relevance of ICT in collective action against the abuse of power (Pierskalla \& Hollenbach, 2013; Weidmann \& Shapiro, 2015; Manacorda \& Tesei, 2016). 


\subsection{Market power and financial access}

Issues surrounding the relationship between market power and financial access have occupied an important part of scholarly research over the past three decades (Stiglitz \& Weiss, 1981; Maudo \& Fernandez de Guevara, 2007; Boateng et al., 2018). Such an interest from scholars was for the most part inspired by the inefficiencies associated with market power, notably: net losses in social and economic welfare (Maudo \& Fernandez de Guevara, 2007). According to dominant narratives in the literature, market power reduces investment, lowers savings, increases financial intermediation inefficiency and decreases avenues of economic prosperity (Stiglitz \& Weiss, 1981; Djankov et al., 2007).

Table 1: Summary of empirical literature on the abuse of market power

\begin{tabular}{lll}
\hline Author(s) & Regions (Period) & Abuse of market power? \\
\hline Tu \& Chen (2000) & Taiwan (1986-1999) & Yes \\
Weill (2004) & Europe (1994-1999) & No \\
Maudos \& de Guevara (2007) & Europe (1993-2002) & No \\
Koetter \& Vins (2008) & Germany (1996-2006) & Yes \\
Koetter et al. (2008) & USA (1986-2006) & No \\
Pruteanu-Podpiera et al. (2008) & Czech Republic (1994-2005) & No \\
Schaeck \& Cihak (2008) & Europe \& USA (1995-2005) & Yes \\
Al-Jarrah \& Gharaibeh (2009) & Jordan (2001-2005) & No \\
Solis \& Maudos (2008) & & No (for deposit market) \\
Al-Muharrami \& Mathews (2009) & Arab Gulf (1993-2002) & Yes (for loans market) \\
Fan \& Marton (2011) & SEE (1998-2008) & No \\
Fu \& Heffernan (2009) & China (1985-2002) & No \\
Delis \& Tsionas (2009) & Europe (1996-2006) & No \\
Fu \& Heffernan (2009) & China (1985-2002) & Yes \\
Punt \&van Rooij(2009) & EU (1992-1997) & No \\
& & No \\
\hline
\end{tabular}




\begin{tabular}{lll}
\hline Ariss (2010) & $\begin{array}{l}\text { A sample of developing countries } \\
(1999-2005)\end{array}$ & Yes (cost efficiency) \\
Coccorese \& Pellecchia (2010) & Italy (1992-2007) & Yes \\
Tetsushi et al. (2014) & Japan (1974-2005) & Yes \\
Titko \& Dauylbaev (2015) & Baltic countries (2007-2013) & No \\
\hline
\end{tabular}

Sources: Coccorese and Pellecchia (2010); Titko and Dauylbaev (2015) and Authors. SEE: South East European countries. EU: Europe Union.

More recent evidence however suggests that in relation to banks with substantial market power, smaller banks are associated with lower interest margins (Beck \& Hesse, 2006;

Ahokpossi, 2013). This suggestion is in line with Beck and Hesse (2006) and Ngigi (2013a, 2013b) who established that bank size substantially affects differences in cost of loans with associated interest rate spreads/margins.

From a theoretical perspective it is expected that banks with higher market power are more likely to maintain lower margins of interest because of economies of scale and other inherent advantages associated with size. Large sized banks may however, pursue objectives of financial intermediation inefficiency with the core purpose of increasing their profit margins (Mitchell \& Onvural, 1996). Unfortunately, the African continent is not receiving the scholarly attention it deserves in the literature on market power, despite being the continent with the most severe constraints to financial access. As summarised in Table 1, with the exception of the study by Ariss (2010) which has sampled a few African countries, the bulk of the literature on market power has not involved the continent.

\subsection{Information sharing and market power}

As recently documented in the literature (Lin et al., 2011; Boateng et al., 2018), the sharing of information can reduce information asymmetry between borrowers and lenders in the banking industry. Information asymmetry in the banking industry is inherently associated with market power because powerful banks use privileged information to extract informational rents from 
borrowers. In accordance with Jappelli and Pagano (2002), the theoretical linkage between information sharing and market power is founded on the anticipation that the former increases competition within the banking sector. This position is consistent with Asongu and Odhiambo (2018) on the connection between information sharing and banking sector competition. Accordingly, the sharing of information increases competition between banks since informational rents that were previously reaped by powerful banks are decreased by information sharing mechanisms. Hence, by reducing market power and rendering credit market contestable, the sharing of information by means of ICT mechanisms, reduces credit constraints and enables efficient capital allocation. However, in spite of the anticipated rewards of information sharing mechanisms, a recent strand of financial access literature is of the position that when information systems are undeveloped, large banks can still reap informational rents associated with their market power (Luoto et al., 2007).

The position that large banks can use information diffusion to increase their margins of profits instead of improving credit access is supported by Brown and Zehnder (2010). Other views maintain that higher interest rates charged by big banks for enhanced profit margins are traceable to the inefficiencies that are associated with the coordination and management of operations in big financial institutions due to diseconomies of scale (Noulas et al., 1990; Mester, 1992; Karray \& Chichti, 2013). Such abuse of market power for greater interest margins has been the premised of a recent strand of African banking literature on information sharing (Barth et al., 2009; Asongu et al., 2016a; Triki \& Gajigo, 2014). Unfortunately, these studies have not directly engaged market power in the assessment of the relevance of information sharing in financial access.

\subsection{Information sharing and financial access}


There is a substantial bulk of literature that is premised on the importance of information sharing in facilitating access to credit (Padilla \& Pagano, 2000; Pagano \& Jappelli, 1993; Karapetyan \& Stacescu, 2014a, 2014b; Boateng et al., 2018). In what follows, we discuss some extant studies on the relevance of information sharing and credit access.

One strand of the literature argues that information sharing reduces adverse selection, mitigates moral hazard, disciplines borrowers and increase competition within the banking sector. In the theoretical models of most studies in this strand (Padilla \& Pagano, 1997, 2000; Jappelli \& Pagano, 2002, 2006; Bennardo et al., 2015), it is argued that the sharing of information reduces difference in information across banks which, increases their abilities to make more informed decisions and lend more to borrowers. Moreover, the perspective that improved information is associated with lower rates of default and more lending is supported by Karapetyan and Stacescu (2014a) and Klein (1992) who have argued that when more information is available to lenders, borrowers are more likely to comply with their financial obligations towards banks. In Africa, Kusi et al. (2017) conclude that the sharing of information reduces bank credit risk, Kusi and Opoku- Mensah (2018) establish that such information sharing mitigates the cost of funding while Muaza and Alagidede (2017) conclude that, the financial access benefits from information sharing are more apparent in English common law countries compared to their French civil law counterparts.

A contending strand of the literature points to the dark side of sharing information. For instance, Jappelli and Pagano (2006) maintain that the sharing of information could also increase lending to riskier borrowers while Dell'Ariccia and Marquez (2006) establish that systematic sharing of information between banks leads to banking crisis. It is also argued in this strand of literature that owing to enhanced information sharing through credit agencies, some banks can consolidate their competitive advantage by collecting more strategic information that is not eventually shared through information sharing mechanisms (Petersen 
\& Rajan, 1995; Vercammen,1995; Hauswald \& Marquez, 2003; Karapetyan \& Stacescu, 2014a, 2014b). The contending strands discussed in this section support the power theories of credit (Townsend, 1979; Stiglitz \& Weiss, 1981; Aghion \& Bolton, 1992) which are premised on the position that the market power of creditors and information represent the two main drivers of credit decisions in the banking industry.

\section{Data and Methodology}

\subsection{Estimation of Market Power (Lerner Index)}

Consistent with recent literature (Boateng et al., 2018; Asongu \& Biekpe, 2018), this study employs the stochastic frontier model for the estimation of the Lerner index which is considered as an indicator of market power. The estimation of the Lerner index from the Battese and Coelli (1992) model is presented in Appendix 1. According to Coccorese and Pellecchia (2010), compared to other models that are based on estimation approaches linked to deterministic frontiers (Aigner \& Chu, 1968; Farrell, 1957), the adopted model is more efficient. This is essentially because the adopted model takes into consideration the fact that, owing to the inefficiency of corporations, gaps between frontier output and observed output could stem from other factors such as measurement errors and stochastic shocks.

Let us assume that for firm $i$ at time $t$, production costs depend on input prices ( $W$ ), output $(Q)$, random error $(v)$ and inefficiency $(u)$.

Assuming that the random error and inefficiency terms are identically and independently distributed (iid), the logarithmic specification associated with the cost function can be presented as follows in Equation (1):

$$
\ln C_{i t}=f\left(Q_{i t}, W_{i t}\right)+v_{i t}+u_{i t}
$$


where the non-negative inefficiency and error term terms are iid, following respectively, a truncated normal distribution and a normal distribution. Therefore, whereas $v_{i t}$ is $N\left(0, \sigma_{v}{ }^{2}\right)$, $u_{i t}$ is $N\left(\mu, \sigma_{u}^{2}\right)$.

The translog cost function is employed in the modelling of the cost. It entails one output and three inputs. The function which was first proposed by Christensen et al. (1971), has been widely employed in the empirical literature (Koetter \& Vins, 2008; Ariss, 2010; Coccorese \& Pellecchia, 2010).

The cost function is as follows in Equation (2):

$$
\begin{aligned}
\ln C_{i t}=\alpha_{0} & +\alpha_{1} \ln Q_{i t}+\sum_{h=1}^{3} \alpha_{h} \ln W_{h i t}+\frac{1}{2}\left\{\alpha_{Q Q}\left(\ln Q_{i t}\right)^{2}+\sum_{h=1}^{3} \sum_{k=1}^{3} \alpha_{h k} \ln W_{h i t} \ln W_{k i t}\right\} \\
& +\sum_{h=1}^{3} \alpha_{Q h} \ln Q_{i t} \ln W_{h i t}+v_{i t}+u_{i t},
\end{aligned}
$$

where $i=1, \ldots \ldots . . N$ and $t=1 \ldots \ldots \ldots . . T$, are subscripts of banks and time respectively. $C$ is the total cost, $Q$ is the output, $W_{h}$ are factor prices, $W_{k}$ are factor quantities and, while $u_{i t}$ and $v_{i t}$ are respectively the error and inefficiency terms.

In the estimation of the cost function, three inputs and one output are specified. The total operating cost is defined with the following: price of labor, price of capital, inputs by the price of deposits and output in terms of total assets and total operating cost measured with overheads $^{2}$. As shown in Equation (4), the Lerner index is computed from the price and the marginal cost. While the latter is derived from the translog cost function's output in Equation (3), the former reflects the price charged by financial institutions on their total assets or

\footnotetext{
${ }^{2}$ The deposit price is calculated by dividing interest expenses by the sum of deposits, short term funding plus money market. The price of labor is defined as the ratio of personnel expenses to total assets. The price of capital is equal to the ratio of 'other operating costs' to the value of fixed assets.
} 
output and it is computed as the ratio of total revenues (net noninterest income plus interest income) to total assets.

$M C_{i t}=\frac{\partial C_{i t}}{\partial Q_{i t}}=\frac{\partial \ln C_{i t}\left(C_{i t}\right)}{\partial \ln Q_{i t}\left(Q_{i t}\right)}=\left(\alpha_{Q}+\alpha_{Q Q} \ln Q_{i t}+\sum_{h=1}^{3} \alpha_{Q h} \ln W_{h i t}\right) \frac{C_{i t}}{Q_{i t}}$

$\operatorname{LERNER}_{i t}=\frac{P_{i t}-M C_{i t}}{P_{i t}}$,

where $P_{i t}$ is the price charged by a bank on its output. From a theoretical perspective, the Lerner index can vary between 0 (in case of perfect competition) and 1 (an exclusive monopoly).

\subsection{Data}

This study examines 39 countries consisting of a panel of 162 banks with data for the period 2001-2011 ${ }^{3}$. The data sources are World Development Indicators of the World Bank and Bankscope. The adopted periodicity, number of countries and number of banks are due to constraints in the availability of data. Market power is proxied with the Lerner index, which represents the ability of banks to set prices above marginal cost ${ }^{4}$. Banks with a higher index are associated with greater market power. The choice of the Lerner index is consistent with recent literature (Ariss, 2010; Boateng et al., 2018). Steps to computing the index used in this study can found in Boateng et al. (2018).

Following recent African ICT literature (Tchamyou, 2017), we use two ICT indicators, namely: the mobile phone penetration rate (per 100 people) and the internet penetration rate (per 100 people). The adoption of these variables is consistent with stylized facts on the high

\footnotetext{
${ }^{3}$ The sampled countries are: Algeria, Angola, Benin, Burkina Faso, Botswana, Burundi, Cameroon, Cape Verde, Central African Republic, Côte d'Ivoire, Eritrea, Equatorial Guinea, Ethiopia, Gabon, Ghana, Kenya, Lesotho, Madagascar, Malawi, Mali, Mauritania, Mauritius, Morocco, Mozambique, Namibia, Niger, Nigeria, Rwanda, Senegal, Seychelles, Sierra Leone, South Africa, Sudan, Swaziland, Tanzania, Togo, Tunisia, Uganda and Zambia. ${ }^{4}$ The lerner index is computed with the translog cost function. Details of the computation are available upon request.
} 
penetration potential of ICT in Africa (Hubani \& Wiese, 2017; Isszhaku \& Wiese, 2017; Minkoua Nzie et al., 2017; Muthinja \& Chipeta, 2017). The dependent variables used in approximation of financial access are: loan price and loan quantity. These are measured respectively with 'price charged on loans' and 'the logarithms of outstanding loan balances' (Coccorese \& Pellecchia, 2010).

Consistent with discussion in the recent African banking literature (see Asongu \& Le Roux, 2016), three categories of control variables are used. These include: (i) market-oriented characteristics (comprising GDP per capita growth; Inflation and Population density); (ii) bank-related features (involving the number of Bank branches and the Deposit/Asset ratio) and (iii) the unobserved firm heterogeneity such as 'compliance with Sharia finance' (NonIslamic versus (vs) Islamic); size (large vs. small) and ownership structure (foreign vs. domestic). The expected signs are discussed in what follows.

First, GDP per capita growth which takes business cycle fluctuations into account should positively influence loan quantity. Conversely, the expected effect on the price of loans is not easy to establish because such impact is contingent on both market dynamism and expansion. Hence, it is proposed that diminishing GDP per capita can influence both loan quantity and loan price in a scenario of decreasing demand. A negative impact may be expected from GDP per capita because over the past decade, GDP has been growing less proportionately than population growth (Asongu, 2013).

Second, we expect the density of the population to positively impact both dependent variables. This is because, from intuition, an increasing demand for loans owing to rising population density is likely to raise loan prices.

Third, the quantity (price) of loans should be logically decreased (increased) with inflation, other things being equal. To be sure, the rate of investment with associated demand for loans is expected to decline in periods of economic uncertainty (like rampant inflation). 
Consequently, the interest charged (or price of the loan) is likely to fall during periods of high inflation. This perception builds on the evidence that investors are more encouraged with less ambiguous economic environments (Kelsey \& Le Roux, 2017a, 2017b).

Fourth, the number of bank branches is expected to positively affect loan quantity and negatively impact the price of loans.

Fifth, raising the 'deposit to asset' ratio is anticipated to increase both the quantity and price of loans. This is primarily because mobilised deposits are the principal source of bank financing. Hence, more liquid liabilities increase interest rate margins and/or quantity of loans, since good organisation and asset-liability management are imperative for the mobilisation of such bank resources.

Sixth, anticipated effects from dummy variables which are used to account for the unobserved heterogeneity are not easy to establish. For instance, regardless of bank size (small versus (vs). big), financial intermediation can be associated with both positive and negative effects resulting from movements in the credit market, although the adverse experience of large financial institutions are expected to be mitigated by their more sophisticated management and coordination systems. Nevertheless, addressing challenges that are naturally linked to the complications of dealing with a larger customer base is likely to be a source of inefficiency for large banks. In the same vein, the influence of heterogeneity in ownership structure (domestic vs. foreign) and 'Sharia finance compliance' (Non-islamic vs. Islamic) are contingent on a plethora of features such as: organisational mission and capacities as well as market dynamics.

Appendix 2 summarises the expected signs whereas Appendix 3, Appendix 4 and Appendix 5 show the definitions of variables (with their corresponding sources), the summary statistics and the correlation matrix in that order. The summary statistics informs that study that the considered variables are comparable in terms of means. Moreover, the corresponding 
standard deviation also informs that study that reasonable estimated linkages can be expected based on the considerable variations of corresponding variables. The correlation matrix is used to avoid concerns about multicollinearity or variables with a high degree of substitution in the conditioning information set.

\subsection{Methodology}

\subsubsection{Generalised Method of Moments: specification, identification and exclusion restrictions}

The adoption of the Generalised Method of Moments (GMM) builds on five principal motivations. The first-two motivations are basic requirements for the choice of the technique whereas the last-three are corresponding advantages of employing the estimation approach. (i) Persistence in the dependent variable is taken into account by the estimation technique. Accordingly, the rule of thumb (0.800) for persistence in loan price and quantity is satisfied because the correlation between these financial access variables and their first lags are respectively 0.845 and 0.996 . (ii) The $\mathrm{T}<\mathrm{N}$ criterion for the GMM strategy is also satisfied because there are 162 banks for a span of 11 years. Therefore, the number of banks $(\mathrm{N})$ is substantially higher than the number of years (T) in each bank. (iii) The estimation approach controls for errors arising from (i) simultaeniety and (ii) time-invariant omitted variables in the regression model. (iv) The use of panel data framework helps to control for the unobserved heterogeneity across our bank units. (v) The system GMM estimator addresses inherent biases that are associated with the difference GMM estimator.

The empirical strategy adopted in this study is the Roodman (2009a, 2009b) extension of Arellano and Bover (1995). In essence, instead of employing the first-difference of the variables as instruments, the technique uses forward orthogonal deviations that have been documented in restrict instrument proliferation and/or limit over-identification (Baltagi, 2008; 
Love \& Zicchino, 2006; Tchamyou, 2018). A two-step procedure is adopted in place of the one-step process because it corrects for heteroscedasticity.

The following equations in level (5) and first difference (6) summarize the estimation procedure for loan quantity.

$$
\begin{aligned}
& L Q_{i, t}=\sigma_{0}+\sigma_{1} L Q_{i, t-\tau}+\sigma_{2} I C T_{i, t}+\sigma_{3} M P_{i, t}+\sigma_{4} \text { Inter }_{i, t}+\sum_{h=1}^{5} \delta_{h} W_{h, i, t-\tau}+\eta_{i}+\xi_{t}+\varepsilon_{i, t} \\
& L Q_{i, t}-L Q_{i, t-\tau}= \sigma_{1}\left(L Q_{i, t-\tau}-L Q_{i, t-2 \tau}\right)+\sigma_{2}\left(I C T_{i, t}-I C T_{i, t-\tau}\right)+\sigma_{3}\left(M P_{i, t}-M P_{i, t-\tau}\right) \\
&+\sigma_{4}\left(\text { Inter }_{i, t}-\text { Inter }_{i, t-\tau}\right)+\sum_{h=1}^{5} \delta_{h}\left(W_{h, i, t-\tau}-W_{h, i, t-2 \tau}\right)+\left(\xi_{t}-\xi_{t-\tau}\right)+\varepsilon_{i, t-\tau}
\end{aligned}
$$

where, $L Q_{i, t}$ is loan quantity of bank $i$ at period $t, \sigma_{0}$ is a constant, $\tau$ represents the coefficient of auto-regression, ICT represents information and communication technology (mobile phone or internet penetration), MP denotes Market Power approximated by the Lerner index, Inter is the interaction between ICT and MP. $W$ is the vector of control variables (GDP per capita growth, Inflation, Population density, Deposit/Assets, Bank Branches)), $\eta_{i}$ are bank-specific effects (Small banks, Domestic banks and Islamic banks), $\xi_{t}$ is the time-specific constant and $\varepsilon_{i, t}$ the error term. Equations (5) and (6) are replicated when the dependent variable is loan price.

It is important to discuss restrictions in identification and exclusion that are essential for a robust GMM specification. In line with the recent literature, we consider all explanatory variables as suspected endogenous or predetermined while the time-invariant omitted variables are considered to be strictly exogenous (Asongu \& Nwachukwu, 2016a). The identification condition is motivated by the awareness that it is not feasible for time-invariant omitted variables or 'years' to be endogenous in first-difference (Roodman, 2009b) . $^{5}$

\footnotetext{
${ }^{5}$ Hence, the process for treating ivstyle (years) is 'iv(years, eq(diff))' while the gmmstyle is used for predetermined variables.
} 
The statistical validity of the underlying exclusion restriction is investigated with the Difference in Hansen Test (DHT) for the exogeneity of instruments. A failure to reject the null hypothesis of DHT implies that years or time invariant omitted variables explain loan price and quantity exclusively through the suspected endogenous variables. In the standard Instrumental Variable (IV) strategy, a rejection of the null hypothesis corresponding to the Sargan Overidentifying Restrictions (OIR) is taken as a signal of the invalidity of the employed instruments (Beck et al., 2003; Asongu \& Nwachukwu, 2016b). This is not the case with the GMM with forward orthogonal deviations which employs the DHT as information criterion for exclusion restriction. Therefore, in the findings that are provided in Section 4, the exclusion restriction assumption is confirmed if the alternative hypothesis of the DHT corresponding to IV (year, eq(diff)) is rejected.

\subsubsection{Instrumental Quantile regressions}

The modelling strategy covered with the GMM strategy is based on mean values of loan price and loan quantity. This represents a shortfall of the implied blanket policies. Moreover, the underlying blanket policies may not be effective across countries with high, intermediate and low existing levels of financial access unless they are related to their initial levels of loan price and quantity. It is important to note that modelling exclusively at the conditional mean of loan price and quantity is addressed with the Quantile Regressions (QR) estimation technique because it examines the linkages throughout the conditional distributions of the dependent variable (Keonker \& Hallock, 2001; Billger \& Goel, 2009; Okada \& Samreth, 2012). Such an approach to understanding credit access has recently been used in clarifying the nexus between information sharing and financial access in Africa (see Asongu et al., 2016b). In the light of the above points, empirical studies that examine such effects with 
Ordinary Least Squares (OLS) are based on the assumption that the errors terms are normally distributed. This proposition does not hold in the QR approach. Furthermore, assessing the robustness of parameter estimates at several points on the conditional distribution of loan price and quantity is consistent when outliers are apparent (Koenker \& Bassett, 1978).

The $\theta^{\text {th }}$ quantile estimator of financial access is obtained by solving the following optimization problem, which is presented without subscripts for simplicity in Eq. (7)

$$
\min _{\beta \in R^{k}}\left[\sum_{i \in\left\{i: y_{i} \geq x_{i^{\prime}} \beta\right.} \theta\left|y_{i}-x_{i^{\prime}} \beta\right|+\sum_{i \in\left\{i: y_{i}<x_{i^{\prime} \beta}\right\}}(1-\theta)\left|y_{i}-x_{i^{\prime}} \beta\right|\right],
$$

where $\theta \in(0,1)$. Contrary to OLS that is fundamentally based on minimizing the sum of squared residuals, with QR, it is the weighted sum of absolute deviations that is minimised. For example, the $25^{\text {th }}$ quartile or $90^{\text {th }}$ decile (with $\theta=0.25$ or 0.90 respectively) are examined by approximately weighing the residuals. The conditional quantile of credit access or $y_{i}$ given $x_{i}$ is expressed as followed:

$Q_{y}\left(\theta / x_{i}\right)=x_{i} \beta_{\theta}$

where unique slope parameters are modelled for each $\theta^{\text {th }}$ specific quantile. This formulation is analogous to $E(y / x)=x_{i^{\prime}} \beta$ in the OLS slope where parameters are examined only at the mean of the conditional distribution of loan price and loan quantity. In Eq. (8), the dependent variable $y_{i}$ is the financial access variable (consisting of loan quantity and loan price respectively) whereas $x_{i}$ contains a constant term, mobile phone penetration, internet penetration, GDP per capita growth, Inflation, Population density, Deposit/Assets, Number of Bank Branches, and bilateral dummy variables representing Small banks, domestic banks and Islamic banks. 
The issue of endogeneity is addressed by instrumenting the ICT variables with their first lags. For instance, the instrumentation process of mobile phone penetration is disclosed in Eq. (9) below.

Mobile $_{i, t}=\alpha+\delta_{j}\left(\right.$ Mobile $\left._{i, t-1}\right)+\eta_{i}+\varepsilon_{i, t}$,

where Mobile $_{i, t}$, is the mobile phone penetration rate of bank $i$ at period $t, \alpha$ is a constant, Mobile $_{i, t-1}$, represents the mobile penetration indicator for bank $i$ at the previous period $t-1, \eta_{i}$ are bank-specific effects and $\varepsilon_{i, t}$ the error term.

The instrumentation process in Eq. (9) which is replicated for internet penetration consists of regressing an ICT variable on its first lags and then saving the fitted values which are then employed as the independent variables of interest in the OLS and QR. The specifications are Heteroscedasticity and Autocorrelation Consistent (HAC) in terms of standard errors. Moreover, through instrumentation, the OLS approach is transformed to a Two Stage Least Squares (2SLS) that accounts for both simultaneity and the unobserved heterogeneity.

\section{Empirical results}

Table 2 below presents the GMM results whereas Tables 3-4 show the findings corresponding to the Quantile regressions. Consistent variations in the estimated coefficients from the Two Stage Least Squares and Quantile regressions (in terms of sign, size and magnitude of significance) justify our decision the adopt Quantile regression method.

For each dimension of financial access in Table 2, there are four specifications: two related to mobile phone penetration and two linked to internet penetration. Both ICT variables have two sub-specifications corresponding to full and partial samples. Whereas the partial 
sample is from 2005 to 2011, the full sample is for the period 2001-2011. The prime motivation underpinning the partial sample is that it helps to restrict instrument proliferation or over-identification since $\mathrm{N}$ is held constant while $\mathrm{T}$ is reduced. It is relevant to note that we are already limiting instrument proliferation by restricting the lag structure of the endogenous variable (which is limited to one) and collapsing instruments in the GMM specification.

However, the partial sample further restricts instrument proliferation because $\mathrm{T}$ is decreased. Four principal information criteria are employed to examine the validity of the GMM model with forward orthogonal deviations ${ }^{6}$ and the findings are discussed based on these information criteria.

The results are discussed in terms of marginal impacts, net effects and thresholds at which the policy variables (mobile phone penetration and internet penetration) influence market power to increase financial access in terms of loan price and loan quantity. For ICT to enhance financial access, marginal effects from interactions with market power should be negative and positive for loan price and loan quantity respectively. For example in the partial sample regression in third column of Table 2, the net impact on average loan prices of using mobile phones to effect changes in market power is positive $(0.014)^{7}$. By contrast, the corresponding marginal effect (or conditional impact of market power) is negative (-0.0007). The implication is that a threshold of 54.285 (i.e., $0.038 / 0.0007$ ) penetration per 100 people is required to reverse the sign of the unconditional effect of market power (0.038) from positive

\footnotetext{
6 "First, the null hypothesis of the second-order Arellano and Bond autocorrelation test (AR(2)) in difference for the absence of autocorrelation in the residuals should not be rejected. Second the Sargan and Hansen overidentification restrictions (OIR) tests should not be significant because their null hypotheses are the positions that instruments are valid or not correlated with the error terms. In essence, while the Sargan OIR test is not robust but not weakened by instruments, the Hansen OIR is robust but weakened by instruments. In order to restrict identification or limit the proliferation of instruments, we have ensured that instruments are lower than the number of cross-sections in most specifications. Third, the Difference in Hansen Test (DHT) for exogeneity of instruments is also employed to assess the validity of results from the Hansen OIR test. Fourth, a Fischer test for the joint validity of estimated coefficients is also provided" (Asongu \& De Moor, 2017, p.200).

${ }^{7}$ The net effect on the average loan price is computed from the interaction between mobile phones and market power on the one hand and unconditional market power effects on the other: That is $0.014=([-0.0007 \times 34.107]+$ 0.038). Where the mean value of mobile phone penetration is 34.107 , the unconditional effect of market power equals 0.038 and the corresponding conditional impact of it estimated to be -0.0007 .
} 
to negative. With respect to the average loan quantity regression, a threshold of 57 penetration per 100 people (i.e., $0.114 / 0.002$ ) is required to counteract the positive impact of market power. These estimated cut-off points are within the mobile phone penetration range of 0.000 to 147.202 provided by the summary statistics. Interestingly, Internet penetration has no apparent impact on both loan price and quantity in all the regressions. Most of the significant control variables display the expected signs.

The quantile regressions are presented in Table 3 and Table 4. The following findings can be established in Table 3 on the role of the mobile phones in mitigating the adverse effect of market power on financial access. There are no statistically significant relationships apparent from the 'loan price'-oriented regressions. By contrast, from the 'loan quantity'related regressions, there are positive marginal effects and net negative effects reported for the bottom and $90^{\text {th }}$ decile. The corresponding thresholds beyond which the unconditional negative effects of market power on loan quantity could be reversed to positive are 56.202, 52.040 and 42.761 penetration per 100 people at the $10^{\text {th }}$ decile, $25^{\text {th }}$ quartile and $90^{\text {th }}$ decile respectively. Most of the significant control variables have the expected signs.

The following findings can be established in Table 4 on the role of internet penetration in reducing market power for financial access. Again, whereas no significantly relevant results are apparent from 'loan price'-oriented regressions, for 'loan quantity'-related regressions, there is a positive marginal effect and net a negative effect only in the $90^{\text {th }}$ decile. The corresponding threshold beyond which the unconditional negative impact of market power on loan quantity could be reversed is 9.485 per 100 people penetration. Again, most of the significant control variables have the expected signs.

The main explanation for the differences in findings throughout the conditional distribution of financial access variables is that, existing levels of access to finance influence the relevance of ICT in modulating the effect of market power on financial access. Moreover, 
it is apparent that mobile phone penetration is a comparatively better ICT policy tool for influencing market power, compared to internet penetration. This can be explained by the fact that the penetration of the internet is lower in the continent compared to mobile phone penetration. For instance, as shown in the summary statistics in Appendix 4, the average mobile phone penetration rate for the sampled countries and periodicity under consideration is $34.107 \%$ while the corresponding average penetration of the internet is $7.268 \%$.

Table 2: Financial access effects of reducing market power with ICT (GMM-IV)

\begin{tabular}{|c|c|c|c|c|c|c|c|c|}
\hline & \multicolumn{8}{|c|}{ Dependent variable: Financial Access } \\
\hline & \multirow{2}{*}{\multicolumn{2}{|c|}{$\begin{array}{l}\text { Loan Price Effects } \\
\text { Mobile Phone Penetration }\end{array}$}} & \multirow{2}{*}{\multicolumn{2}{|c|}{ Internet Penetration }} & \multirow{2}{*}{\multicolumn{2}{|c|}{$\begin{array}{l}\text { Loan Quantity Effects } \\
\text { Mobile Phone Penetration }\end{array}$}} & \multirow{2}{*}{\multicolumn{2}{|c|}{ Internet Penetration }} \\
\hline & & & & & & & & \\
\hline & Full Sample & $\begin{array}{l}\text { Partial } \\
\text { Sample }\end{array}$ & $\begin{array}{l}\text { Full } \\
\text { Sample }\end{array}$ & $\begin{array}{l}\text { Partial } \\
\text { Sample }\end{array}$ & Full Sample & $\begin{array}{l}\text { Partial } \\
\text { Sample }\end{array}$ & $\begin{array}{l}\text { Full } \\
\text { Sample }\end{array}$ & $\begin{array}{l}\text { Partial } \\
\text { Sample }\end{array}$ \\
\hline Constant & $\begin{array}{l}0.028 * * \\
(0.013)\end{array}$ & $\begin{array}{l}-0.204 * * \\
(0.014)\end{array}$ & $\begin{array}{l}0.042 * * * \\
(0.001)\end{array}$ & $\begin{array}{l}-0.013 \\
(0.767)\end{array}$ & $\begin{array}{l}0.502 * * * \\
(0.000)\end{array}$ & $\begin{array}{l}0.153 \\
(0.439)\end{array}$ & $\begin{array}{l}0.261 * * * \\
(0.000)\end{array}$ & $\begin{array}{l}-0.064 \\
(0.699)\end{array}$ \\
\hline Price of Loans $(-1)$ & $\begin{array}{l}0.580 * * * \\
(0.000)\end{array}$ & $\begin{array}{l}0.549 * * * \\
(0.000)\end{array}$ & $\begin{array}{l}0.571 * * * \\
(0.000)\end{array}$ & $\begin{array}{l}\mathbf{0 . 7 7 8} * * * \\
(\mathbf{0 . 0 0 0 )}\end{array}$ & --- & --- & --- & --- \\
\hline Quantity of Loans (-1) & & -- & --- & --- & $\begin{array}{l}0.959 * * * \\
(0.000)\end{array}$ & $\begin{array}{l}1.026 * * * \\
(0.000)\end{array}$ & $\begin{array}{l}0.992 * * * \\
(0.000)\end{array}$ & $\begin{array}{l}1.012 * * * \\
(0.000)\end{array}$ \\
\hline Market Power & $\begin{array}{l}0.009 \\
(0.296)\end{array}$ & $\begin{array}{l}0.038 * * \\
(0.023)\end{array}$ & $\begin{array}{l}-0.012 \\
(0.204)\end{array}$ & $\begin{array}{l}0.009 \\
(0.516)\end{array}$ & $\begin{array}{l}-0.062 \\
(0.330)\end{array}$ & $\begin{array}{l}0.114 * * \\
(0.041)\end{array}$ & $\begin{array}{l}-0.080 \\
(0.127)\end{array}$ & $\begin{array}{l}0.042 \\
(0.498)\end{array}$ \\
\hline Mobile & $\begin{array}{l}0.0001 \\
(0.230)\end{array}$ & $\begin{array}{l}0.0002 \\
(0.155)\end{array}$ & --- & --- & $\begin{array}{l}-0.001 \\
(0.107)\end{array}$ & $\begin{array}{l}0.001 * * \\
(0.043)\end{array}$ & --- & --- \\
\hline Internet & --- & --- & $\begin{array}{l}-0.0001 \\
(0.688)\end{array}$ & $\begin{array}{l}-0.00005 \\
(0.916)\end{array}$ & --- & --- & $\begin{array}{l}-0.001 \\
(0.624)\end{array}$ & $\begin{array}{l}0.001 \\
(0.430)\end{array}$ \\
\hline Mobile×Market Power & $\begin{array}{l}-0.0003 \\
(0.127)\end{array}$ & $\begin{array}{l}-0.0007 * * * \\
(0.006)\end{array}$ & --- & --- & $\begin{array}{l}0.0001 \\
(0.897)\end{array}$ & $\begin{array}{l}-0.002 * * * \\
(0.009)\end{array}$ & --- & --- \\
\hline Internet $\times$ Market Power & --- & --- & $\begin{array}{l}0.0008 \\
(0.261)\end{array}$ & $\begin{array}{l}-0.0001 \\
(0.845)\end{array}$ & --- & --- & $\begin{array}{l}-0.002 \\
(0.430)\end{array}$ & $\begin{array}{l}-0.001 \\
(0.718)\end{array}$ \\
\hline GDPpcg & $\begin{array}{l}0.0001 \\
(0.676)\end{array}$ & $\begin{array}{l}0.0008 \\
(0.105)\end{array}$ & $\begin{array}{l}0.0001 \\
(0.730)\end{array}$ & $\begin{array}{l}0.00007 \\
(0.838)\end{array}$ & $\begin{array}{l}0.004 * * * \\
(\mathbf{0 . 0 0 5})\end{array}$ & $\begin{array}{l}0.007 * * * \\
(0.001)\end{array}$ & $\begin{array}{l}0.005 * * * \\
(0.001)\end{array}$ & $\begin{array}{l}0.006 * * * \\
(0.004)\end{array}$ \\
\hline Inflation & $\begin{array}{l}0.0001 * * \\
(0.031)\end{array}$ & $\begin{array}{l}-0.0000004 \\
(0.995)\end{array}$ & $\begin{array}{l}0.0002 * * * \\
(0.002)\end{array}$ & $\begin{array}{l}\text { 0.0001* } \\
(0.098)\end{array}$ & $\begin{array}{l}-0.0001 \\
(0.207)\end{array}$ & $\begin{array}{l}-0.00009 \\
(0.336)\end{array}$ & $\begin{array}{l}0.00003 \\
(0.723)\end{array}$ & $\begin{array}{l}-0.00004 \\
(0.598)\end{array}$ \\
\hline Pop. density & $\begin{array}{l}0.00003 * * \\
(0.011)\end{array}$ & $\begin{array}{l}-0.000001 \\
(0.959)\end{array}$ & $\begin{array}{l}0.00002 * * * \\
(0.002)\end{array}$ & $\begin{array}{l}0.00002 * * \\
(0.037)\end{array}$ & $\begin{array}{l}-0.0001 \\
(0.229)\end{array}$ & $\begin{array}{l}0.00006 \\
(0.424)\end{array}$ & $\begin{array}{l}0.00006 \\
(0.183)\end{array}$ & $\begin{array}{l}0.00004 \\
(0.590)\end{array}$ \\
\hline Deposit/Assets & 0.024 & 0.042 & $0.029 *$ & $0.086 * *$ & $-0.165 *$ & 0.156 & $-0.189 * *$ & 0.150 \\
\hline
\end{tabular}




\begin{tabular}{|c|c|c|c|c|c|c|c|c|}
\hline & $(0.102)$ & $(0.123)$ & $(0.051)$ & $(0.011)$ & $(0.095)$ & $(0.162)$ & $(0.014)$ & $(0.197)$ \\
\hline \multirow[t]{2}{*}{ Bank Branches } & -0.0003 & $-0.001 * *$ & $-0.001 * * *$ & $-0.001 * *$ & $0.003 *$ & -0.002 & 0.001 & $-0.004 * *$ \\
\hline & $(0.342)$ & $(\mathbf{0 . 0 3 3 )}$ & $(0.001)$ & $(\mathbf{0 . 0 3 5})$ & $(0.074)$ & $(0.297)$ & $(0.456)$ & $(0.026)$ \\
\hline Net effect of Mobile & na & 0.014 & --- & --- & na & 0.045 & --- & --- \\
\hline Threshold of Mobile & na & 54.285 & --- & --- & na & nsa & --- & --- \\
\hline Net effect of Internet & --- & --- & na & na & --- & --- & na & na \\
\hline Threshold of Internet & --- & --- & na & na & --- & --- & na & na \\
\hline $\operatorname{AR}(1)$ & $(0.000)$ & $(0.057)$ & $(0.000)$ & $(0.159)$ & $(0.001)$ & $(0.001)$ & $(0.001)$ & $(0.000)$ \\
\hline $\operatorname{AR}(2)$ & $(0.080)$ & $(0.168)$ & (0.129) & $(0.497)$ & $(0.025)$ & $(0.341)$ & $(0.029)$ & $(0.823)$ \\
\hline Sargan OIR & $(0.000)$ & $(0.012)$ & $(0.000)$ & $(0.002)$ & $(0.000)$ & $(0.055)$ & $(0.000)$ & $(0.019)$ \\
\hline Hansen OIR & $(0.009)$ & $(0.400)$ & $(0.010)$ & $(0.258)$ & $(0.018)$ & $(0.101)$ & $(0.005)$ & (0.149) \\
\hline \multirow{2}{*}{\multicolumn{9}{|c|}{$\begin{array}{l}\text { DHT for instruments } \\
\text { (a)Instruments in levels }\end{array}$}} \\
\hline & & & & & & & & \\
\hline $\mathrm{H}$ excluding group & $(0.147)$ & $(0.103)$ & $(0.125)$ & $(0.405)$ & $(\mathbf{0 . 3 0 3})$ & $(0.225)$ & (0.219) & $(0.104)$ \\
\hline Dif(null, $\mathrm{H}=$ exogenous) & $(0.013)$ & $(0.744)$ & $(0.016)$ & $(0.233)$ & $(0.013)$ & $(0.127)$ & $(0.004)$ & $(0.324)$ \\
\hline \multicolumn{9}{|l|}{ (b) IV (years, eq(diff)) } \\
\hline $\mathrm{H}$ excluding group & $(0.044)$ & $(0.267)$ & $(0.165)$ & $(0.435)$ & (0.177) & $(0.156)$ & $(0.005)$ & (0.141) \\
\hline Dif(null, $\mathrm{H}=$ exogenous) & $(0.031)$ & $(0.706)$ & $(0.004)$ & (0.133) & $(0.019)$ & $(0.164)$ & (0.179) & (0.349) \\
\hline Fisher & $66.03 * * *$ & $32.29 * * *$ & $53.45 * * *$ & $28.60 * * *$ & $797.57 * * *$ & $2774.03 * * *$ & $1613.18 * * *$ & $2248.70 * * *$ \\
\hline Instruments & 42 & 41 & 42 & 41 & 42 & 41 & 42 & 41 \\
\hline Banks & 135 & 108 & 135 & 107 & 137 & 108 & 137 & 107 \\
\hline Observations & 646 & 139 & 633 & 138 & 656 & 139 & 643 & 138 \\
\hline
\end{tabular}

*,**,***: significance levels of 10\%, 5\% and 1\% respectively. DHT: Difference in Hansen Test for Exogeneity of Instruments' Subsets. Dif: Difference. OIR: Over-identifying Restrictions Test. The significance of bold values is twofold. 1) The significance of estimated coefficients and the Fisher statistics. 2) The failure to reject the null hypotheses of: a) no autocorrelation in the AR(1) andAR(2) tests and; b) the validity of the instruments in the OIR and DHT tests. na: not applicable due to the insignificance of marginal effects. nsa: not specifically applicable because the threshold effect is contrary to theoretical underpinnings. Mean value of Mobile is 34.107. Mean value of Internet is 7.268. Range of Mobile: 0.000 to 147.202. Range of Internet is 0.037 to 51.000. 
Table 3: Financial Access Effects of reducing Market Power with Mobile Phone (2SLS and IV QR)

\begin{tabular}{|c|c|c|c|c|c|c|c|c|c|c|c|c|}
\hline & $\begin{array}{l}\text { Depende } \\
\text { Loan Price }\end{array}$ & $\begin{array}{l}\text { ariable: } \\
\text { ects }\end{array}$ & ancial Acc & & & & Loan Quant & Effects & & & & \\
\hline & 2SLS & Q.10 & Q.25 & Q.50 & Q.75 & Q.90 & 2SLS & Q.10 & Q.25 & Q.50 & Q.75 & Q.90 \\
\hline Constant & $\begin{array}{l}\mathbf{0 . 1 1 7} * * * \\
(\mathbf{0 . 0 0 0 )}\end{array}$ & $\begin{array}{l}0.056 \\
(0.274)\end{array}$ & $\begin{array}{l}0.107 * * * \\
(0.000)\end{array}$ & $\begin{array}{l}0.104 * * * \\
(0.001)\end{array}$ & $\begin{array}{l}0.120 * * * \\
(0.000)\end{array}$ & $\begin{array}{l}0.166 * * * \\
(0.000)\end{array}$ & $\begin{array}{l}6.083 * * * \\
(0.000)\end{array}$ & $\begin{array}{l}4.455 * * * \\
(0.000)\end{array}$ & $\begin{array}{l}5.941 * * * \\
(0.000)\end{array}$ & $\begin{array}{l}\mathbf{5 . 8 7 4} * * * \\
(0.000)\end{array}$ & $\begin{array}{l}\mathbf{5 . 3 8 2} * * * \\
(\mathbf{0 . 0 0 0 )}\end{array}$ & $\begin{array}{l}6.614 * * * \\
(0.000)\end{array}$ \\
\hline Market Power (IV) & $\begin{array}{l}-0.014 \\
(0.770)\end{array}$ & $\begin{array}{l}0.014 \\
(0.879)\end{array}$ & $\begin{array}{l}-0.032 \\
(0.513)\end{array}$ & $\begin{array}{l}0.008 \\
(0.865)\end{array}$ & $\begin{array}{l}-0.0001 \\
(0.997)\end{array}$ & $\begin{array}{l}-0.055 \\
(0.383)\end{array}$ & $\begin{array}{l}-4.758 * * * \\
(0.000)\end{array}$ & $\begin{array}{l}-4.159 * * * \\
(0.002)\end{array}$ & $\begin{array}{l}-5.152 * * * \\
(0.005)\end{array}$ & $\begin{array}{l}-4.719 * \\
(0.076)\end{array}$ & $\begin{array}{l}-2.875^{*} \\
(0.070)\end{array}$ & $\begin{array}{l}-2.694 * * * \\
(0.000)\end{array}$ \\
\hline Mobile (IV) & $\begin{array}{l}-0.0002 \\
(0.742)\end{array}$ & $\begin{array}{l}0.0002 \\
(0.871)\end{array}$ & $\begin{array}{l}-0.0002 \\
(0.662)\end{array}$ & $\begin{array}{l}0.00004 \\
(0.950)\end{array}$ & $\begin{array}{l}0.0002 \\
(0.758)\end{array}$ & $\begin{array}{l}-0.0001 \\
(0.867)\end{array}$ & $\begin{array}{l}-0.053 * * * \\
(0.004)\end{array}$ & $\begin{array}{l}-0.037 * * \\
(\mathbf{0 . 0 4 3})\end{array}$ & $\begin{array}{l}-0.051 * * \\
(0.041)\end{array}$ & $\begin{array}{l}-0.054 \\
(0.135)\end{array}$ & $\begin{array}{l}-0.028 \\
(0.190)\end{array}$ & $\begin{array}{l}-0.029 * * * * \\
(0.001)\end{array}$ \\
\hline Mobile(IV) $\times$ Market Power(IV) & $\begin{array}{l}0.0002 \\
(0.797)\end{array}$ & $\begin{array}{l}-0.0005 \\
(0.805)\end{array}$ & $\begin{array}{l}0.0007 \\
(0.518)\end{array}$ & $\begin{array}{l}-0.0001 \\
(0.932)\end{array}$ & $\begin{array}{l}-0.0005 \\
(0.678)\end{array}$ & $\begin{array}{l}0.0002 \\
(0.849)\end{array}$ & $\begin{array}{l}\text { 0.101*** } \\
(0.002)\end{array}$ & $\begin{array}{l}0.074 * * \\
(0.019)\end{array}$ & $\begin{array}{l}0.099 * * \\
(0.022)\end{array}$ & $\begin{array}{l}0.096 \\
(0.126)\end{array}$ & $\begin{array}{l}0.061 \\
(0.100)\end{array}$ & $\begin{array}{l}\mathbf{0 . 0 6 3} * * * \\
(\mathbf{0 . 0 0 0 )}\end{array}$ \\
\hline GDPpcg & $\begin{array}{l}-0.0007 * \\
(\mathbf{0 . 0 8 8})\end{array}$ & $\begin{array}{l}-0.0007 \\
(0.276)\end{array}$ & $\begin{array}{l}0.0001 \\
(0.801)\end{array}$ & $\begin{array}{l}-0.0005 \\
(0.293)\end{array}$ & $\begin{array}{l}-0.0006 \\
(0.333)\end{array}$ & $\begin{array}{l}-0.00008 \\
(0.919)\end{array}$ & $\begin{array}{l}-0.008 \\
(0.515)\end{array}$ & $\begin{array}{l}0.013 \\
(0.190)\end{array}$ & $\begin{array}{l}-0.036 * * \\
(0.030)\end{array}$ & $\begin{array}{l}-0.031 \\
(0.262)\end{array}$ & $\begin{array}{l}-0.004 \\
(0.789)\end{array}$ & $\begin{array}{l}-0.009 \\
(0.125)\end{array}$ \\
\hline Inflation & $\begin{array}{l}0.0001 \\
(0.138)\end{array}$ & $\begin{array}{l}0.00005 \\
(0.214)\end{array}$ & $\begin{array}{l}\text { 0.0001** } \\
(\mathbf{0 . 0 2 9})\end{array}$ & $\begin{array}{l}0.0001 * * \\
(0.028)\end{array}$ & $\begin{array}{l}0.0003 * * * \\
(0.000)\end{array}$ & $\begin{array}{l}0.001 * * * \\
(0.000)\end{array}$ & $\begin{array}{l}0.002 * \\
(0.076)\end{array}$ & $\begin{array}{l}0.002^{* * * *} \\
(0.000)\end{array}$ & $\begin{array}{l}0.006 * * * * \\
(0.001)\end{array}$ & $\begin{array}{l}0.004 \\
(0.184)\end{array}$ & $\begin{array}{l}0.002 \\
(0.260)\end{array}$ & $\begin{array}{l}\text { 0.0008* } \\
(0.077)\end{array}$ \\
\hline Pop. Density & $\begin{array}{l}0.00002 \\
(0.116)\end{array}$ & $\begin{array}{l}\text { 0.00004* } \\
(0.061)\end{array}$ & $\begin{array}{l}0.00004 * * * \\
(0.000)\end{array}$ & $\begin{array}{l}0.00001 \\
(0.259)\end{array}$ & $\begin{array}{l}0.00001 \\
(0.447)\end{array}$ & $\begin{array}{l}-0.00001 \\
(0.480)\end{array}$ & $\begin{array}{l}-0.0008 * * * \\
(0.008)\end{array}$ & $\begin{array}{l}-0.0003 * \\
(0.068)\end{array}$ & $\begin{array}{l}0.0002 \\
(0.494)\end{array}$ & $\begin{array}{l}-0.0001 \\
(0.871)\end{array}$ & $\begin{array}{l}-0.001 * \\
(0.098)\end{array}$ & $\begin{array}{l}-0.0008 * \\
(0.077)\end{array}$ \\
\hline Deposit/Assets & $\begin{array}{l}0.005 \\
(0.555)\end{array}$ & $\begin{array}{l}0.009 \\
(0.504)\end{array}$ & $\begin{array}{l}0.003 \\
(0.660)\end{array}$ & $\begin{array}{l}0.004 \\
(0.665)\end{array}$ & $\begin{array}{l}0.012 \\
(0.264)\end{array}$ & $\begin{array}{l}0.004 \\
(0.724)\end{array}$ & $\begin{array}{l}2.095 * * * * \\
(0.000)\end{array}$ & $\begin{array}{l}\mathbf{1 . 0 5 8}^{* * * *} \\
(\mathbf{0 . 0 0 0 )}\end{array}$ & $\begin{array}{l}1.746 * * * \\
(0.000)\end{array}$ & $\begin{array}{l}2.234 * * * \\
(0.000)\end{array}$ & $\begin{array}{l}\text { 2.370**** } \\
(\mathbf{0 . 0 0 0 )}\end{array}$ & $\begin{array}{l}1.243 * * * \\
(0.000)\end{array}$ \\
\hline Bank Branches & $\begin{array}{l}-0.002 * * * \\
(0.000)\end{array}$ & $\begin{array}{l}-0.002 * * * * \\
(0.000)\end{array}$ & $\begin{array}{l}-0.003 * * * \\
(0.000)\end{array}$ & $\begin{array}{l}-0.002 * * * \\
(0.000)\end{array}$ & $\begin{array}{l}-0.001 * * * \\
(0.002)\end{array}$ & $\begin{array}{l}-0.002 * * * \\
(0.002)\end{array}$ & $\begin{array}{l}-0.065 * * * \\
(0.000)\end{array}$ & $\begin{array}{l}-0.016 * * \\
(0.031)\end{array}$ & $\begin{array}{l}-0.061 * * * \\
(0.000)\end{array}$ & $\begin{array}{l}-0.067 * * * \\
(0.002)\end{array}$ & $\begin{array}{l}-0.087 * * * \\
(0.000)\end{array}$ & $\begin{array}{l}-0.073 * * * * \\
(0.000)\end{array}$ \\
\hline Small Banks & $\begin{array}{l}0.008 * * \\
(0.030)\end{array}$ & $\begin{array}{l}0.015^{*} \\
(0.058)\end{array}$ & $\begin{array}{l}0.004 \\
(0.238)\end{array}$ & $\begin{array}{l}0.001 \\
(0.677)\end{array}$ & $\begin{array}{l}0.011 * * \\
(0.028)\end{array}$ & $\begin{array}{l}0.011 \\
(0.102)\end{array}$ & $\begin{array}{l}-0.809 * * * \\
(0.000)\end{array}$ & $\begin{array}{l}-0.674 * * * \\
(0.000)\end{array}$ & $\begin{array}{l}-1.306 * * * \\
(0.000)\end{array}$ & $\begin{array}{l}-0.752 * * * \\
(0.003)\end{array}$ & $\begin{array}{l}-0.527 * * * \\
(0.003)\end{array}$ & $\begin{array}{l}-0.430 * * * \\
(0.000)\end{array}$ \\
\hline Domestic Banks & $\begin{array}{l}0.003 \\
(0.333)\end{array}$ & $\begin{array}{l}-0.004 \\
(0.425)\end{array}$ & $\begin{array}{l}0.0004 \\
(0.877)\end{array}$ & $\begin{array}{l}0.006 * \\
(0.079)\end{array}$ & $\begin{array}{l}0.006 \\
(0.155)\end{array}$ & $\begin{array}{l}0.007 \\
(0.265)\end{array}$ & $\begin{array}{l}0.308 * * * \\
(0.005)\end{array}$ & $\begin{array}{l}0.021 \\
(0.824)\end{array}$ & $\begin{array}{l}0.240 * \\
(0.092)\end{array}$ & $\begin{array}{l}0.516 * * \\
(0.015)\end{array}$ & $\begin{array}{l}0.510 * * * \\
(0.000)\end{array}$ & $\begin{array}{l}0.425 * * * \\
(0.000)\end{array}$ \\
\hline Islamic Banks & $\begin{array}{l}-0.022 * * * \\
(0.003)\end{array}$ & $\begin{array}{l}0.0001 \\
(0.992)\end{array}$ & $\begin{array}{l}-0.022 * * * * \\
(0.007)\end{array}$ & $\begin{array}{l}-0.038 * * * \\
(0.000)\end{array}$ & $\begin{array}{l}-0.014 \\
(0.242)\end{array}$ & $\begin{array}{l}-0.027 * * \\
(0.034)\end{array}$ & $\begin{array}{l}-0.417 * * \\
(0.034)\end{array}$ & $\begin{array}{l}0.283 \\
(0.144)\end{array}$ & $\begin{array}{l}-0.166 \\
(0.653)\end{array}$ & $\begin{array}{l}-0.302 \\
(0.585)\end{array}$ & $\begin{array}{l}-0.529 \\
(0.139)\end{array}$ & $\begin{array}{l}-1.142 * * * \\
(0.000)\end{array}$ \\
\hline Net effect of the Mobile & na & na & na & na & na & na & -1.019 & -1.419 & -1.487 & na & na & -0.361 \\
\hline Threshold of Mobile & na & na & na & na & na & na & 47.108 & 56.202 & 52.040 & na & na & 42.761 \\
\hline Pseudo $R^{2} / R^{2}$ & 0.124 & 0.098 & 0.094 & 0.075 & 0.075 & 0.068 & 0.218 & 0.089 & 0.115 & 0.156 & 0.132 & 0.130 \\
\hline Fisher & $8.29 * * *$ & & & & & & $27.50 * * *$ & & & & & \\
\hline Observations & 620 & 620 & 620 & 620 & 620 & 620 & 620 & 620 & 620 & 620 & 620 & 620 \\
\hline
\end{tabular}

where financial access is least. na: not applicable due to the insignificance of marginal effects and/or unconditional effect of market power. Mean value of IVMobile is 37.019 . Range of IVMobile: 4.332 to 152.599. 
Table 4: Financial Access Effects of reducing Market Power with the Internet (2SLS and IV QR)

\begin{tabular}{|c|c|c|c|c|c|c|c|c|c|c|c|c|}
\hline & \multicolumn{6}{|c|}{$\begin{array}{l}\text { Dependent variable: Financial Access } \\
\text { Loan Prices Effects }\end{array}$} & \multicolumn{6}{|c|}{ Loan Quantity Effects } \\
\hline & 2SLS & Q.10 & Q.25 & Q.50 & Q.75 & Q.90 & 2SLS & Q.10 & Q.25 & Q.50 & Q.75 & Q.90 \\
\hline Constant & $\begin{array}{l}0.128 * * * \\
(0.000)\end{array}$ & $\begin{array}{l}0.065 * * \\
(0.019)\end{array}$ & $\begin{array}{l}0.111 * * * \\
(0.000)\end{array}$ & $\begin{array}{l}0.120 * * * \\
(0.000)\end{array}$ & $\begin{array}{l}0.162 * * * \\
(0.000)\end{array}$ & $\begin{array}{l}0.174 * * * \\
(0.000)\end{array}$ & $\begin{array}{l}4.485 * * * \\
(0.000)\end{array}$ & $\begin{array}{l}3.597 * * * \\
(0.000)\end{array}$ & $\begin{array}{l}2.924 * * * \\
(0.005)\end{array}$ & $\begin{array}{l}3.473 * * * \\
(0.000)\end{array}$ & $\begin{array}{l}4.321 * * * \\
(0.000)\end{array}$ & $\begin{array}{l}\text { 7.650**** } \\
(0.000)\end{array}$ \\
\hline Market Power (IV) & $\begin{array}{l}-0.024 \\
(0.499)\end{array}$ & $\begin{array}{l}-0.0004 \\
(0.992)\end{array}$ & $\begin{array}{l}-0.027 \\
(0.501)\end{array}$ & $\begin{array}{l}-0.013 \\
(0.700)\end{array}$ & $\begin{array}{l}-0.043 \\
(0.231)\end{array}$ & $\begin{array}{l}-0.060 \\
(0.282)\end{array}$ & $\begin{array}{l}-1.833 * \\
(0.071)\end{array}$ & $\begin{array}{l}-2.463^{*} \\
(0.067)\end{array}$ & $\begin{array}{l}-0.317 \\
(0.845)\end{array}$ & $\begin{array}{l}-0.410 \\
(0.764)\end{array}$ & $\begin{array}{l}-1.045 \\
(0.130)\end{array}$ & $\begin{array}{l}-2.637 * * * \\
(0.000)\end{array}$ \\
\hline Internet (IV) & $\begin{array}{l}-0.001 \\
(0.436)\end{array}$ & $\begin{array}{l}0.0001 \\
(0.955)\end{array}$ & $\begin{array}{l}-0.002 \\
(0.452)\end{array}$ & $\begin{array}{l}-0.001 \\
(0.560)\end{array}$ & $\begin{array}{l}-0.001 \\
(0.627)\end{array}$ & $\begin{array}{l}-0.003 \\
(0.338)\end{array}$ & $\begin{array}{l}-0.069 \\
(0.318)\end{array}$ & $\begin{array}{l}-0.083 \\
(0.350)\end{array}$ & $\begin{array}{l}0.052 \\
(0.632)\end{array}$ & $\begin{array}{l}0.049 \\
(0.585)\end{array}$ & $\begin{array}{l}-0.020 \\
(0.654)\end{array}$ & $\begin{array}{l}-\mathbf{0 . 1 3 1} \text { **** } \\
(0.000)\end{array}$ \\
\hline Internet(IV)×Market Power(IV) & $\begin{array}{l}0.002 \\
(0.520)\end{array}$ & $\begin{array}{l}-0.0008 \\
(0.867)\end{array}$ & $\begin{array}{l}0.003 \\
(0.479)\end{array}$ & $\begin{array}{l}0.002 \\
(0.600)\end{array}$ & $\begin{array}{l}0.001 \\
(0.685)\end{array}$ & $\begin{array}{l}0.005 \\
(0.428)\end{array}$ & $\begin{array}{l}0.157 \\
(0.204)\end{array}$ & $\begin{array}{l}0.182 \\
(0.261)\end{array}$ & $\begin{array}{l}-0.078 \\
(0.687)\end{array}$ & $\begin{array}{l}-0.022 \\
(0.892)\end{array}$ & $\begin{array}{l}0.094 \\
(0.252)\end{array}$ & $\begin{array}{l}0.278 * * * \\
(0.000)\end{array}$ \\
\hline GDPpcg & $\begin{array}{l}-0.0007 * \\
(0.096)\end{array}$ & $\begin{array}{l}-0.0007 \\
(0.309)\end{array}$ & $\begin{array}{l}-0.0004 \\
(0.459)\end{array}$ & $\begin{array}{l}-0.0006 \\
(0.247)\end{array}$ & $\begin{array}{l}-0.0002 \\
(0.703)\end{array}$ & $\begin{array}{l}0.0002 \\
(0.794)\end{array}$ & $\begin{array}{l}-0.014 \\
(0.262)\end{array}$ & $\begin{array}{l}0.012 \\
(0.164)\end{array}$ & $\begin{array}{l}-0.013 \\
(0.457)\end{array}$ & $\begin{array}{l}0.001 \\
(0.964)\end{array}$ & $\begin{array}{l}-0.017 \\
(0.262)\end{array}$ & $\begin{array}{l}-0.026 * * \\
(0.030)\end{array}$ \\
\hline Inflation & $\begin{array}{l}0.0001 \\
(0.123)\end{array}$ & $\begin{array}{l}0.00005 \\
(0.220)\end{array}$ & $\begin{array}{l}0.0001 \\
(0.175)\end{array}$ & $\begin{array}{l}0.0001 * * \\
(0.046)\end{array}$ & $\begin{array}{l}0.0003 * * * \\
(0.000)\end{array}$ & $\begin{array}{l}0.0005 * * * * \\
(0.000)\end{array}$ & $\begin{array}{l}0.002 \\
(0.100)\end{array}$ & $\begin{array}{l}0.002 * * * \\
(0.000)\end{array}$ & $\begin{array}{l}0.005^{* *} \\
(0.010)\end{array}$ & $\begin{array}{l}0.003 \\
(0.244)\end{array}$ & $\begin{array}{l}0.001 \\
(0.317)\end{array}$ & $\begin{array}{l}0.0008 \\
(0.145)\end{array}$ \\
\hline Pop. Density & $\begin{array}{l}0.00002 * * \\
(0.032)\end{array}$ & $\begin{array}{l}\text { 0.00004* } \\
(0.066)\end{array}$ & $\begin{array}{l}0.00004 * * \\
(0.013)\end{array}$ & $\begin{array}{l}0.00003 * \\
(0.075)\end{array}$ & $\begin{array}{l}0.000008 \\
(0.637)\end{array}$ & $\begin{array}{l}0.000008 \\
(0.700)\end{array}$ & $\begin{array}{l}-0.001 * * * \\
(0.002)\end{array}$ & $\begin{array}{l}-0.001 * * * \\
(0.000)\end{array}$ & $\begin{array}{l}-0.00004 \\
(0.923)\end{array}$ & $\begin{array}{l}-0.00006 \\
(0.920)\end{array}$ & $\begin{array}{l}-0.001 * * * \\
(0.005)\end{array}$ & $\begin{array}{l}-0.001 * * * * \\
(0.000)\end{array}$ \\
\hline Deposit/Assets & $\begin{array}{l}-0.0001 \\
(0.989)\end{array}$ & $\begin{array}{l}0.010 \\
(0.479)\end{array}$ & $\begin{array}{l}-0.003 \\
(0.766)\end{array}$ & $\begin{array}{l}-0.0003 \\
(0.976)\end{array}$ & $\begin{array}{l}-0.003 \\
(0.746)\end{array}$ & $\begin{array}{l}0.005 \\
(0.726)\end{array}$ & $\begin{array}{l}2.099 * * * \\
(0.000)\end{array}$ & $\begin{array}{l}1.228 * * * \\
(0.000)\end{array}$ & $\begin{array}{l}2.091 * * * \\
(0.000)\end{array}$ & $\begin{array}{l}2.279 * * * \\
(0.000)\end{array}$ & $\begin{array}{l}2.641 * * * \\
(0.000)\end{array}$ & $\begin{array}{l}0.264 \\
(0.165)\end{array}$ \\
\hline Bank Branches & $\begin{array}{l}-0.002 * * * \\
(0.000)\end{array}$ & $\begin{array}{l}-0.003 * * * * \\
(0.000)\end{array}$ & $\begin{array}{l}-0.003 * * * \\
(0.000)\end{array}$ & $\begin{array}{l}-0.002 * * * \\
(0.000)\end{array}$ & $\begin{array}{l}-0.002 * * * \\
(0.003)\end{array}$ & $\begin{array}{l}-0.002 * * \\
(0.018)\end{array}$ & $\begin{array}{l}-0.070 * * * * \\
(0.000)\end{array}$ & $\begin{array}{l}-0.022 * * \\
(0.034)\end{array}$ & $\begin{array}{l}-0.037 * * \\
(0.048)\end{array}$ & $\begin{array}{l}-0.101 * * * * \\
(0.000)\end{array}$ & $\begin{array}{l}-0.095 * * * \\
(0.000)\end{array}$ & $\begin{array}{l}-0.078 * * * * \\
(0.000)\end{array}$ \\
\hline Small Banks & $\begin{array}{l}0.008^{*} \\
(0.057)\end{array}$ & $\begin{array}{l}0.014 * \\
(0.067)\end{array}$ & $\begin{array}{l}0.008 \\
(0.154)\end{array}$ & $\begin{array}{l}0.004 \\
(0.429)\end{array}$ & $\begin{array}{l}0.002 \\
(0.634)\end{array}$ & $\begin{array}{l}0.011 \\
(0.211)\end{array}$ & $\begin{array}{l}-0.785 * * * \\
(0.000)\end{array}$ & $\begin{array}{l}-0.672 * * * \\
(0.000)\end{array}$ & $\begin{array}{l}-1.313 * * * \\
(0.000)\end{array}$ & $\begin{array}{l}-0.905 * * * \\
(0.000)\end{array}$ & $\begin{array}{l}-0.572 * * * \\
(0.000)\end{array}$ & $\begin{array}{l}-0.689 * * * \\
(0.000)\end{array}$ \\
\hline Domestic Banks & $\begin{array}{l}0.003 \\
(0.306)\end{array}$ & $\begin{array}{l}-0.006 \\
(0.251)\end{array}$ & $\begin{array}{l}0.001 \\
(0.819)\end{array}$ & $\begin{array}{l}0.008^{*} \\
(0.060)\end{array}$ & $\begin{array}{l}0.008 \\
(0.111)\end{array}$ & $\begin{array}{l}0.011 \\
(0.145)\end{array}$ & $\begin{array}{l}0.332 * * * * \\
(\mathbf{0 . 0 0 3})\end{array}$ & $\begin{array}{l}-0.004 \\
(0.965)\end{array}$ & $\begin{array}{l}0.267 \\
(0.118)\end{array}$ & $\begin{array}{l}0.370 * * \\
(0.044)\end{array}$ & $\begin{array}{l}0.621 * * * \\
(0.000)\end{array}$ & $\begin{array}{l}0.566 * * * \\
(0.000)\end{array}$ \\
\hline Islamic Banks & $\begin{array}{l}-0.030 * * * \\
(0.000)\end{array}$ & $\begin{array}{l}-0.0006 \\
(0.972)\end{array}$ & $\begin{array}{l}-0.025^{*} \\
(0.053)\end{array}$ & $\begin{array}{l}-0.040^{* * * *} \\
(0.004)\end{array}$ & $\begin{array}{l}-0.050 * * * \\
(0.001)\end{array}$ & $\begin{array}{l}-0.035 \\
(0.108)\end{array}$ & $\begin{array}{l}-0.432 * \\
(0.092)\end{array}$ & $\begin{array}{l}0.227 \\
(0.419)\end{array}$ & $\begin{array}{l}-0.068 \\
(0.881)\end{array}$ & $\begin{array}{l}-0.512 \\
(0.344)\end{array}$ & $\begin{array}{l}-0.499 \\
(0.163)\end{array}$ & $\begin{array}{l}-1.220 * * * * \\
(0.000)\end{array}$ \\
\hline Net effect of the Internet & na & na & na & na & na & na & na & na & na & na & na & -0.466 \\
\hline Threshold of Internet & na & na & na & na & na & na & na & na & na & na & na & 9.485 \\
\hline Pseudo $\mathrm{R}^{2} / \mathrm{R}^{2}$ & 0.131 & 0.103 & 0.095 & 0.082 & 0.077 & 0.072 & 0.201 & 0.079 & 0.104 & 0.149 & 0.113 & 0.116 \\
\hline Fisher & $7.64 * * *$ & & & & & & $25.45 * * *$ & & & & & \\
\hline Observations & 601 & 601 & 601 & 601 & 601 & 601 & 601 & 601 & 601 & 601 & 601 & 601 \\
\hline
\end{tabular}

where financial access is least. na: not applicable due to the insignificance of marginal effects and/or unconditional effect of market power. Mean value of IVInternet is 7.809 . Range of IVInternet is 0.786 to 57.230 . 


\section{Conclusions and future research directions}

This study has assessed how information diffusion dampens the adverse effect of market power on financial access. It focuses on a panel of 162 banks from 39 African countries for the period 2001-2011. The empirical evidence is based on three simultaneity-robust estimation techniques, namely: (i) Two-Stage Least Squares (2SLS), (ii) Generalised Method of Moments (GMM) and (iii) Instrumental Variable Quantile Regressions (QR). The following key results are identified. First, from the GMM findings, a mobile phone penetration rate of 54.285 and 57 per 100 people neutralises the positive effect of market power on loan price and quantity in that order. Second, from the QR, mobile phone penetration rates of $56.202,52.040$ and 42.761 per 100 people nullify the estimated negative effect of market power on loan quantity provided by the formal banking sector at the $10^{\text {th }}$ decile, $25^{\text {th }}$ quartile and $90^{\text {th }}$ decile respectively while the corresponding counteracting threshold of internet penetration is considerably lower at 9.485 per 100 people only at the $90^{\text {th }}$ decile. On average, between 2009 and 2011: (i) countries that do not meet the mobile phone penetration thresholds are Eritrea, Burundi, Ethiopia, Madagascar, Malawi, Mozambique, Niger, Rwanda and Sierra Leon and (ii) countries that meet the internet penetration threshold are Algeria, Angola, Cape Verde, Ghana, Kenya, Mauritius, Morocco, Namibia, Nigeria, Senegal, Seychelles, South Africa, Sudan, Swaziland, Tanzania, Tunisia, Uganda and Zambia.

The decision to complement an estimation technique, such as the GMM-IV approach which is based on conditional mean values of the dependent variable with a QR method that is based on multiple points of the conditional distribution of the dependent variable is apparent from our findings. These have revealed that blanket policies of information diffusion for the purpose of dampening market power for financial access may not be effective unless they are contingent on the initial levels of financial access across countries. 
A likely explanation as to why information diffusion reduces the adverse impact of market power on access to credit is related to the fact that innovative schemes such as mobile banking have helped to decrease the over-reliance on the formal banking sector for loans. Such could encourage banks, especially the large size financial institutions to lower ( raise) the price (quantity) of loans in the formal credit market.

In the light of the above, the policy and practical implications of this study are fivefold: First, market power in the African banking industry may be so strong that its effect on financial access cannot easily be modulated by ICT of low penetration. Hence, the insignificant findings should not be observed in the light of publication bias or the file drawer concern in social sciences, where compared to strong results that are more likely to be published, insignificant and null findings are not published and discarded (Rosenberg, 2005; Franco et al., 2014). The insignificance of ICT in modulating market power therefore has economic meaning if market power is high and/or information diffusion by means of ICT is low.

Second, policies designed to boost ICT penetration in Africa would disproportionately increase the quantity of loan provided by the formal banking sector by reducing their market power in the African financial industry. Third, the statistically insignificant coefficient reported in the QR regressions for loan price is taken as an indication that ICT could be supplemented with other tools such as information sharing offices (involving public credit registries and private credit bureaus). Such complementarity should also be contingent on the initial levels of financial access in the country concerned. In summary, by adopting measures of universal ICT access, policy makers can substantially increase access to credit by households and corporations. Such universal access schemes may include the liberalisation of the ICT sector aimed at speeding up internet connections at relatively low prices. 
Fourth, the above policies are not recommended in the light of a "one size fits all" kind of policy framework. For instance, countries with lower levels of loan quantity should be given more priority in internet penetration because we have seen that only countries at the top quantiles of loan quantity can potentially benefits from the role of the internet in modulating the effect of market power on financial access.

Fifth, information shared through ICT mechanisms in Africa may not be of high quality in terms of accuracy, correctness and comprehensiveness. This is could also explain the insignificant relationships. Moreover, the insignificant nexuses could also be traceable to the absence of appropriate institutional frameworks, presence of weak legal systems and poor regulations governing ICT mechanisms.

The factors in the fifth point, which are not explicitly considered in the regressions also double as a limitation of the study. Hence, future studies can focus on assessing how the suggested factors affect the established linkages. Another limitation of the study is that the policy prescriptions are not country-specific. Therefore, it is also worthwhile to assess whether the established linkages withstand empirical scrutiny from country-specific standpoints, in order to prescribe more targeted country-specific policy implications. Future inquires devoted to improve extant literature can also focus on alternative instruments with which market power can be dampened in order to enhance financial access in the African banking industry. For instance, the roles of information sharing offices, mobile banking and financial sector competition can be considered. 


\section{Appendices}

\section{Appendix 1: Estimates of the Cost Function}

\begin{tabular}{llll} 
Parameters & Regressors & $\begin{array}{l}\text { Battese-Coelli } \\
\text { Coefficients }\end{array}$ & $\begin{array}{l}\text { Standard } \\
\text { Errors }\end{array}$ \\
\hline$\alpha_{0}$ & Constant & $-0.2502^{* * *}$ & 0.1358 \\
$\alpha_{Q}$ & $\ln Q$ & $0.8683^{* * *}$ & 0.0331 \\
$\alpha_{1}$ & $\ln W_{1}$ & 0.0559 & 0.0623 \\
$\alpha_{2}$ & $\ln W_{2}$ & $0.5919^{* * *}$ & 0.1143 \\
$\alpha_{3}$ & $\ln W_{3}$ & $0.2037^{* * *}$ & 0.0557 \\
$\alpha_{Q Q}$ & $(\ln Q)^{2} / 2$ & $0.0127^{*}$ & 0.0067 \\
$\alpha_{11}$ & $\left(\ln W_{1}\right)^{2} / 2$ & -0.0139 & 0.0242 \\
$\alpha_{22}$ & $\left(\ln W_{2}\right)^{2} / 2$ & $-0.1034^{*}$ & 0.0614 \\
$\alpha_{33}$ & $\left(\ln W_{3}\right)^{2} / 2$ & $-0.0935^{* * *}$ & 0.0262 \\
$\alpha_{Q 1}$ & $\ln Q \times \ln W_{1}$ & $-0.0389^{* * * *}$ & 0.0086 \\
$\alpha_{12}$ & $\ln W_{1} \times \ln W_{2}$ & -0.0214 & 0.0305 \\
$\alpha_{13}$ & $\ln W_{1} \times \ln W_{3}$ & 0.0335 & 0.0271 \\
$\alpha_{Q 2}$ & $\ln Q \times \ln W_{2}$ & -0.0068 & 0.0130 \\
$\alpha_{23}$ & $\ln W_{2} \times \ln W_{3}$ & -0.0240 & 0.0279 \\
$\alpha_{Q 3}$ & $\ln Q \times \ln W_{3}$ & 0.0003 & 0.0078 \\
Log-likelihood & & 1021.2181 & \\
Wald Chi-square & & $19818.07 * * *$ & \\
Observations & & 900 & \\
Banks & & 151 & \\
\hline
\end{tabular}

***,***: significance levels of $1 \%, 5 \%$ and $10 \%$ respectively. 
Appendix 2: Summary of expected signs

\begin{tabular}{llll}
\hline & Variables & $\begin{array}{l}\text { Expected sign on loan } \\
\text { price }\end{array}$ & $\begin{array}{l}\text { Expected sign on loan } \\
\text { quantity }\end{array}$ \\
\cline { 2 - 4 } $\begin{array}{l}\text { Bank-oriented } \\
\text { features }\end{array}$ & $\begin{array}{l}\text { Deposit/Asset ratio } \\
\text { Bank Branches }\end{array}$ & + & + \\
Market-related & - & + \\
characteristics & GDP per capita growth & Uncertain & + \\
& Population density & + & + \\
Characteristics of the & Inflation & + & - \\
unobserved & Small versus(vs). Big banks & Uncertain & Uncertain \\
heterogeneity & domestic vs. foreign banks & Uncertain & Uncertain \\
\hline
\end{tabular}

\section{Appendix 3: Variable Definitions}

\begin{tabular}{|c|c|c|c|}
\hline Variables & Signs & Variable Definitions & Sources \\
\hline Mobile Phones & Mobile & Mobile phone subscriptions (per 100 people) & WDI (World Bank) \\
\hline Internet Penetration & Internet & Internet penetration (per 100 people) & WDI (World Bank) \\
\hline Market Power & Lerner index & $\begin{array}{l}\text { The ratio of the 'difference between the } \\
\text { Marginal Cost and Price' on the Price }\end{array}$ & $\begin{array}{l}\text { Authors' calculation } \\
\text { and BankScope }\end{array}$ \\
\hline Loan Quantity & Quantity & Logarithm of Loans Quantity & BankScope \\
\hline $\begin{array}{l}\text { Price (charged on } \\
\text { Loans or Quantity) }\end{array}$ & Price & $\begin{array}{l}\text { (Gross Interest and Dividend income +Total } \\
\text { Non-Interest Operating Income)/Total Assets }\end{array}$ & BankScope \\
\hline GDP per capita & GDP & GDP per capita growth (annual \%) & WDI (World Bank) \\
\hline Inflation & Infl. & Consumer Price Index (annual \%) & WDI (World Bank) \\
\hline Populaton density & Pop. & People per square kilometers of land area & WDI (World Bank) \\
\hline Deposits/Assets & $\mathrm{D} / \mathrm{A}$ & Deposits on Total Assets & BankScope \\
\hline Bank Branches & Bbrchs & $\begin{array}{l}\text { Number of Bank Branches (Commercial bank } \\
\text { branches per } 100000 \text { adults) }\end{array}$ & BankScope \\
\hline Small Banks & & $\begin{array}{l}\text { Ratio of Bank Assets to Total Assets (Assets } \\
\text { in all Banks for a given period) } \leq 0.50\end{array}$ & $\begin{array}{l}\text { Authors' calculation } \\
\text { and BankScope }\end{array}$ \\
\hline Large Banks & & $\begin{array}{l}\text { Ratio of Bank Assets to Total Assets (Assets } \\
\text { in all Banks for a given period) }>0.50\end{array}$ & $\begin{array}{l}\text { Authors' calculation } \\
\text { and BankScope }\end{array}$ \\
\hline $\begin{array}{l}\text { Domestic/Foreign } \\
\text { banks }\end{array}$ & Dom/Foreign & $\begin{array}{l}\text { Domestic/Foreign banks based on qualitative } \\
\text { information: creation date, headquarters, } \\
\text { government/private ownership, \% of foreign } \\
\text { ownership, year of foreign/domestic } \\
\text { ownership...etc }\end{array}$ & $\begin{array}{l}\text { Authors' qualitative } \\
\text { content analysis. }\end{array}$ \\
\hline Islamic/Non-Islamic & Islam/NonIsl. & $\begin{array}{l}\text { Islamic/Non-Islamic banks based on financial } \\
\text { statement characteristics (trading in } \\
\text { derivatives and interest on loan } \\
\text { payments...etc) }\end{array}$ & $\begin{array}{l}\text { Authors' qualitative } \\
\text { content analysis; Beck } \\
\text { et al. (2010); Ali } \\
\text { (2012). }\end{array}$ \\
\hline
\end{tabular}

WDI: World Development Indicators. GDP: Gross Domestic Product. The following are dummy variables: Ssize, Lsize, Open, Close, Dom/Foreign and Islam/NonIsl. 
Appendix 4: Summary Statistics

\begin{tabular}{lllllll}
\hline & & & & & \\
ICT & Mean & S.D & Minimum & Maximum & Observations \\
\cline { 2 - 6 } & Internet & 34.107 & 32.409 & 0.000 & 147.202 & 1776 \\
Market & Lerner & 7.268 & 8.738 & 0.037 & 51.000 & 1757 \\
Power & & 0.513 & 0.587 & 0.032 & 0.969 & 893 \\
Dependent & Price of Loans & & & & & \\
variables & Quantity of Loans (ln) & 0.338 & 0.929 & 0.000 & 25.931 & 1045 \\
& & 3.747 & 1.342 & -0.045 & 6.438 & 1091 \\
Market & GDP per capita growth & 13.912 & 96.707 & -15.306 & 926.61 & 1782 \\
variables & Inflation & 10.239 & 22.695 & -9.823 & 325.00 & 1749 \\
& Population density & 81.098 & 106.06 & 2.085 & 633.52 & 1782 \\
\hline \multirow{2}{*}{ Bank level } & Deposits/Assets & 0.664 & 0.198 & 0.000 & 1.154 & 1052 \\
variables & Bank Branches & 6.112 & 6.158 & 0.383 & 37.209 & 1129 \\
& Small Size & 0.195 & 0.396 & 0.000 & 1.000 & 1255 \\
& Large Size & 0.804 & 0.396 & 0.000 & 1.000 & 1255 \\
& Domestic & 0.753 & 0.431 & 0.000 & 1.000 & 1782 \\
Dummy & Foreign & 0.246 & 0.431 & 0.000 & 1.000 & 1782 \\
variables & Islamic & 0.037 & 0.188 & 0.000 & 1.000 & 1782 \\
& Non-Islamic & 0.962 & 0.188 & 0.000 & 1.000 & 1782 \\
\hline
\end{tabular}

Ln: Logarithm. GDP: Gross Domestic Product. S.D: Standard Deviation. GDP: Gross Domestic Product. 


\section{Appendix 5: Correlation Matrix}

\begin{tabular}{|c|c|c|c|c|c|c|c|c|c|c|c|c|c|c|c|c|}
\hline \multicolumn{3}{|c|}{ Market-Level Controls } & \multicolumn{4}{|c|}{ Bank-Level Controls } & \multicolumn{6}{|c|}{ Dummy-Controls } & \multicolumn{2}{|l|}{ ICT } & \multirow[t]{2}{*}{ Lerner } & \multirow[b]{3}{*}{ GDP } \\
\hline & Infl. & Pop. & $\mathrm{D} / \mathrm{A}$ & Bbrchs & Price & Quantity & Ssize & Lsize & Dom. & Foreign & Islam & NonIsl. & Mobile & Internet & & \\
\hline \multirow[t]{16}{*}{1.000} & 0.136 & 0.007 & -0.008 & -0.068 & $\begin{array}{c}-0.014 \\
\end{array}$ & -0.026 & -0.0002 & 0.0002 & 0.034 & -0.034 & 0.0001 & -0.0001 & -0.261 & -0.122 & -0.016 & \\
\hline & 1.000 & -0.028 & 0.037 & -0.236 & 0.256 & -0.009 & 0.046 & -0.046 & 0.028 & -0.028 & -0.050 & 0.050 & -0.315 & -0.238 & -0.062 & Inf. \\
\hline & & 1.000 & 0.112 & 0.410 & -0.029 & -0.125 & -0.098 & 0.098 & -0.045 & 0.045 & -0.088 & 0.088 & 0.056 & 0.335 & 0.035 & Pop. \\
\hline & & & 1.000 & -0.041 & 0.080 & 0.306 & -0.041 & 0.041 & -0.062 & 0.062 & -0.210 & 0.210 & -0.087 & -0.036 & 0.021 & $\mathrm{D} / \mathrm{A}$ \\
\hline & & & & 1.000 & -0.266 & -0.227 & -0.078 & 0.078 & 0.135 & -0.135 & -0.051 & 0.051 & 0.610 & 0.747 & 0.109 & Bbrchs \\
\hline & & & & & 1.000 & -0.075 & 0.094 & -0.094 & 0.016 & -0.016 & -0.097 & 0.097 & -0.206 & -0.219 & 0.082 & Price \\
\hline & & & & & & 1.000 & -0.171 & 0.171 & 0.052 & -0.052 & -0.067 & 0.067 & -0.096 & -0.118 & -0.038 & Quantity \\
\hline & & & & & & & 1.000 & -1.000 & 0.026 & -0.026 & -0.020 & 0.020 & 0.146 & 0.089 & -0.056 & Ssize \\
\hline & & & & & & & & 1.000 & -0.026 & 0.026 & 0.020 & -0.020 & -0.146 & -0.089 & 0.056 & Lsize \\
\hline & & & & & & & & & 1.000 & -1.000 & 0.089 & -0.089 & 0.151 & 0.039 & 0.147 & Dom. \\
\hline & & & & & & & & & & 1.000 & -0.089 & 0.089 & -0.151 & 0.039 & -0.147 & Foreign \\
\hline & & & & & & & & & & & 1.000 & -1.000 & -0.045 & -0.039 & 0.006 & Islam \\
\hline & & & & & & & & & & & & 1.000 & 0.045 & -0.032 & -0.006 & NonIsl. \\
\hline & & & & & & & & & & & & & 1.000 & 0.634 & 0.089 & Mobile \\
\hline & & & & & & & & & & & & & & 1.000 & 0.048 & Internet \\
\hline & & & & & & & & & & & & & & & 1.000 & Lerner \\
\hline
\end{tabular}

Info: Information. GDP: GDP per capita growth. Infl: Inflation. Pop: Population growth. D/A: Deposit on Total Assets. Bbrchs: Bank branches. Szize: Small banks. Lsize: Large banks. Domestic: Domestic banks. Foreign: Foreign banks. Islam: Islamic banks. NonIsl: Non-Islamic banks. Price: Price of Loans. Quantity: Quantity of Loans. ICT: Information and Communication Technology. Mobile: mobile phone penetration. Internet: internet penetration. Lerner: Market Power 


\section{Acknowledgement}

-The authors are indebted to the editor and reviewers for constructive comments.

\section{References}

Afutu-Kotey, R. L. , Gough, K. W., \& Owusu, G., (2017). "Young Entrepreneurs in the Mobile Telephony Sector in Ghana: From Necessities to Aspirations”, Journal of African Business, 18(4), pp. 476-491.

Aghion, P., \& Bolton, P. (1992). “An incomplete contracts approach to corporate bankruptcy", Review of Economic Studies, 59(3), pp. 473-494.

Ahokpossi, C., (2013). "Determinants of bank interest margins in Sub-Saharan Africa", IMF Working Paper No. 13/34, Washington.

https://www.imf.org/en/Publications/WP/Issues/2016/12/31/Determinants-of-Bank-InterestMargins-in-Sub-Saharan-Africa-40289 (Accessed: 13/04/2018).

Aigner, D. J., \& Chu, S. F., (1968). “On Estimating the Industry Production Function”, American Economic Review, 58(4), pp. 826-839.

Al-Jarrah, I. M., \& Gharaibeh, H., (2009). “The Efficiency Cost of Market Power in the Banking Industry: A Test of the "Quiet Life" and Related Hypotheses in the Jordan Banking Industry", Investment Management and Financial Innovations, 6(2), pp. 32-39

Al-Muharrami, S., \& Methews, K., (2009), "Market Power Versus Efficient-Structure in Arab GCC Banking”, Applied Financial Economics, 19(18), pp. 1487-1496. 
Ali, S. S., (2012). "Islamic Banking in the MENA Region”, Islamic Research and Training Institute (IRTI), Working Paper Series No. 1433-01, Jeddah.

Arellano, M., \& Bover, O., (1995). “Another look at the instrumental variable estimation of error components models", Journal of Econometrics, 68(1), pp. 29-52.

Ariss, R. T., (2010). “On the Implications of Market Power in Banking: Evidence from Developing Countries”, Journal of Banking and Finance, 34(4), pp. 765-775.

Asongu, S. A., (2013). "How Would Population Growth Affect Investment in the Future? Asymmetric Panel Causality Evidence for Africa", African Development Review, 25(1), pp. 14-29.

Asongu, S. A., (2014). “Correcting Inflation with Financial Dynamic Fundamentals: Which Adjustments Matter in Africa?”, Journal of African Business, 15(1), pp. 64-73.

Asongu, S. A., (2018). “Conditional Determinants of Mobile Phones Penetration and Mobile Banking in Sub-Saharan Africa”, Journal of the Knowledge Economy, 9(1), pp. 81-135.

Asongu, S. A., \& Anyanwu, J. C., \& Tchamyou, S. V., (2016b). "Information sharing and conditional financial development in Africa", African Governance and Development Institute Working Paper No. 16/001, Yaoundé.

https://papers.ssrn.com/sol3/papers.cfm?abstract id=2722516 (Accessed: 13/04/2018). 
Asongu, S. A., \& Biekpe, N., (2018). "ICT, information asymmetry and market power in African banking industry", Research in International Business and Finance.

DOI: 10.1016/j.ribaf.2017.07.121

https://www.sciencedirect.com/science/article/pii/S0275531917303185?via\%3Dihub

Asongu, S. A, \& De Moor, L., (2017). "Financial Globalisation Dynamic Thresholds for Financial Development: Evidence from Africa", European Journal of Development Research, 29(1), pp. 192-212.

Asongu, S. A., \& Le Roux, S., (2016). "Reducing Information Asymmetry with ICT: A critical review of loan price and quantity effects in Africa", African Governance and Development Institute Working Paper No. 16/024, Yaoundé.

https://ideas.repec.org/p/agd/wpaper/16-024.html (Accessed: 13/04/2018).

Asongu, S. A, \& Nwachukwu, J. C., (2016a). "The Mobile Phone in the Diffusion of Knowledge for Institutional Quality in Sub Saharan Africa”, World Development, 86(October), pp. 133-147.

Asongu, S. A, \& Nwachukwu, J. C., (2016b). "Foreign aid and governance in Africa", International Review of Applied Economics, 30(1), pp. 69-88.

Asongu, S. A., \& Nwachukwu, J. C., (2016c). "The Role of Governance in Mobile Phones for Inclusive Human Development in Sub-Saharan Africa", Technovation, 55-56 (SeptemberOctober), pp. 1-13. 
Asongu, S. A., Nwachukwu, J., \& Tchamyou, S. V., (2016a). "Information Asymmetry and Financial Development Dynamics in Africa”, Review of Development Finance, 6(2), pp. 126138.

Asongu, S. A., \& Odhiambo, N., (2018). "Information Asymmetry, Financialization and Financial Access", International Finance: Forthcoming.

Baltagi, B. H., (2008). "Forecasting with panel data", Journal of Forecasting, 27(2), pp. 153173.

Battese, G. E., \& Coelli, T. J., (1992). "Frontier Production Function, Technical Efficiency and Panel Data with Application to Paddy Farmers in India”, Journal of Productivity Analysis, 3(1), pp. 153-169.

Bartels, F. L., Alladina, S. N., \& Lederer, S., (2009), "Foreign Direct Investment in SubSaharan Africa: Motivating Factors and Policy Issues", Journal of African Business, 10(2), pp. 141-162.

Barth, J., Lin, C., Lin, P., \& Song, F., (2009). "Corruption in bank lending to firms: crosscountry micro evidence on the beneficial role of competition and information sharing", Journal of Financial Economics, 99(3), pp. 361-368.

Beck, T., Demirgüç-Kunt, A., \& Levine, R., (2003). "Law and finance: why does legal origin matter?", Journal of Comparative Economics, 31(4), pp. 653-675. 
Beck, T., Demirguc-Kunt, A., \& Merrouche, O., (2010). "Islamic vs. Conventional Banking: Business Model, Efficiency and Stability”, World Bank Policy Research Working Paper No. 5446, Washington.

https://openknowledge.worldbank.org/handle/10986/3929 (Accessed: 13/04/2018).

Beck, T., \& Hesse, H., (2006). "Bank efficiency, ownership and market structure: why are interest spreads so high in Uganda?", Policy Research Working Paper Series No. 4027, The World Bank, Washington.

https://papers.ssrn.com/sol3/papers.cfm?abstract_id=1804923 (Accessed: 13/04/2018).

Bergemanny, D., Heumannz, T., \& Morris, S., (2015). “Information and Market Power”, Department of Economics, Yale University, New Haven, https://economics.wustl.edu/files/economics/imce/bergemann_paper.pdf (Accessed: $16 / 08 / 2016)$.

Bennardo, A., Pagano, M., \& Piccolo, S. (2015). "Multiple-bank lending, creditor rights, and information sharing, Review of Finance, 19(2), pp.519-570.

Billger, S. M., \& Goel, R. K., (2009). "Do existing corruption levels matter in controlling corruption? Cross-country quantile regression estimates", Journal of Development Economics, 90(2), pp. 299-305.

Boateng, A., Asongu, S. A., Akamavi, R., \& Tchamyou, V. S., (2018). "Information Asymmetry and Market Power in the African Banking Industry”, Journal of Multinational Financial Management, 44(March), pp. 69-83. 
Bongomin, G. O. C., Ntayi, J. M., Munene J. C., \& Malinga, C. A., (2018). “Mobile Money and Financial Inclusion in Sub-Saharan Africa: the Moderating Role of Social Networks", Journal of African Business. DOI: 10.1080/15228916.2017.1416214.

https://www.tandfonline.com/doi/abs/10.1080/15228916.2017.1416214

Boulianne, S., (2009). “Does Internet Use Affect Engagement? A Meta-Analysis of Research", Political Communication, 26(2), pp. 193-211.

Brown, M., \& Zehnder, C., (2010). “The emergence of information sharing in credit markets”. Journal of Financial Intermediation, 19(2), pp. 255-278.

Carson, R. T., \& Sun, Y. (2007). "The Tobit model with a non-zero threshold", Econometrics Journal, 10(3), pp. 488-502.

Christensen, L. R., Jorgenson, D. W., \& Lau, L. J., (1971). “Transcendental Logarithmic Production Frontiers", Review of Economics and Statistics, 55(1), pp. 28-45.

Coccorese, P., \& Pellecchia, A., (2010). “Testing the 'Quiet Life' Hypothesis in the Italian Banking Industry", Economic Notes by Banca dei Paschi di Siena SpA, 39(3), pp. 173-202.

Darley, W. K., (2012), “Increasing Sub-Saharan Africa's Share of Foreign Direct Investment: Public Policy Challenges, Strategies, and Implications", Journal of African Business, 13(1), 28, pp. 62-69. 
Dell'Ariccia, G. \& Marquez, R. (2004). “Information and bank credit allocation”, Journal of Financial Economics, 72(1), pp.185-214.

Delis, M. D., \& Tsionas, E. G., (2009), “The Joint Estimation of Bank-Level Market Power and Efficiency”, Journal of Banking and Finance, 33(10), pp. 1842-1850.

Dewan, S., \& Ramaprasad, J., (2014). "Social media, traditional media and music sales", MIS Quarterly, 38(1), pp. 101-128.

Diamond, L., (2010). “Liberation Technology”, Journal of Democracy, 21(3), pp. 69-83.

Djankov, S., McLiesh, C., \& Shleifer, A. (2007). "Private credit in 129 countries". Journal of Financial Economics, 84(2), pp.299-329.

Fang, Y., \& Marton, K., (2011). "Bank Efficiency in Transition Economies: Recent Evidence from South-Eastern Europe", Research Discussion Papers No. 5/2011, Helsinki: Bank of Finland.

https://papers.ssrn.com/sol3/papers.cfm?abstract_id=1804923 (Accessed: 13/04/2018).

Farrell, M. J., (1957). “The Measurement of Productive Efficiency”, Journal of Royal Statistics Society, 120(3), pp. 253-290.

Fouda, O. J. P., (2009), “The excess liquidity of banks in Franc zone: how to explain the paradox in the CEMAC", Revue Africaine de l'Integration, 3(2), pp. 1-56. 
Franco, A., Malhotra, N., \& Simonovits, G., (2014). "Publication Bias in the Social Sciences: Unlocking the File Drawer", Science, 345(6203), pp. 1502-1505.

Fu, X., \& Heffernan, S., (2009), “The Effects of Reform on China's Bank Structure and Performance", Journal of Banking and Finance, 33(1), pp. 39-52.

Gosavi, A., (2017). "Can mobile money help firms mitigate the problem of access to finance in Eastern sub-Saharan Africa", Journal of African Business. DOI: 10.1080/15228916.2017.1396791.

https://www.tandfonline.com/doi/abs/10.1080/15228916.2017.1396791

Grossman, G., Humphreys, M., and Sacramone-Lutz, G., (2014). ““'I wld like u WMP to extend electricity 2 our village": On Information Technology and Interest Articulation", American Political Science Review, 108(3), pp. 688-705.

Hart, O., \& Moore, J., (1994). "A theory of debt based on the inalienability of human capital”, Quarterly Journal of Economics, 109(4), pp. 841-879.

Hauswald, R \& Marquez, R. (2003). "Information technology and financial services competition", Review of Financial Studies, 16(3), pp.921-948.

Hellstrom, J. (2008), “Mobile phones for good governance- challenges and way forward", Stockholm University / UPGRAID, http://www.w3.org/2008/10/MW4D_WS/papers/hellstrom_gov.pdf (Accessed: 22/11/2015). 
Hubani, M., \& Wiese, M., (2017). “A Cashless Society for All: Determining Consumers’ Readiness to Adopt Mobile Payment Services”, Journal of African Business, DOI:

10.1080/15228916.2017.1396792.

https://www.tandfonline.com/doi/abs/10.1080/15228916.2017.1396792

Issahaku, H., Abu, B. M., \& Nkegbe, P. K., (2017). “Does the Use of Mobile Phones by Smallholder Maize Farmers Affect Productivity in Ghana?", Journal of African Business DOI: $10.1080 / 15228916.2017 .1416215$.

https://www.tandfonline.com/doi/abs/10.1080/15228916.2017.1416215

Jaffee, D., \& Russel, T. (1976). "Imperfect information, uncertainty and credit rationing", Quarterly Journal of Economics, 90(4), pp. 651-666.

Jappelli, T., \& Pagano, M., (2002). "Information sharing, lending and default: Cross-country evidence", Journal of Banking \& Finance, 26(10), pp. 2017-2045.

Jappelli, T., \& Pagano, M., (2006). Role and effects of credit information sharing. In Bertola, G., Disney, R., \& Grant, C. (Eds.), The Economics of Consumer Credit, MIT Press, Cambridge, pp. 347-371.

Karapetyan, A., \& Stacescu, B., (2014a). "Information Sharing and Information Acquisition in Credit Markets", Review of Finance, 18(6), pp. 2247-2281.

Karapetyan, A., \& Stacescu, B., (2014b). "Does information sharing reduce the role of collateral as a screening device?", Journal of Banking and Finance, 43( C), pp. 48-57. 
Karray, S. C., \& Chichti, J. E., (2013). "Bank size and efficiency in developing countries: intermediation approach versus value added approach and impact of non-traditional activities", Asian Economic and Financial Review, 3(5), pp. 593-613.

Kelsey, D. \& Le Roux, S., (2017a). "Strategic Ambiguity and Decision-making: An Experimental Study”, Theory \& Decision, DOI: 10.1007/s11238-017-9618-8.

Kelsey D \& Le Roux, S., (2017b). “Dragon Slaying with Ambiguity: Theory and Experiments", Journal of Public Economic Theory, 19(1), pp. 178-197.

Klein, D. B. (1992). "Promise keeping in the great society: A model of credit sharing information sharing”, Economics \& Politics, 4(2), pp117-136.

Koetter, M., Kolari, J. W., \& Spierduk, L., (2008). "Efficient Competition ? Testing the 'Quiet Life' of U.S Banks with Adjusted Lerner Indices”, Proceedings of the $44^{\text {th }}$ 'Bank Structure and Competition' Conference, Federal Reserve Bank of Chicago. https://www.researchgate.net/profile/James_Kolari/publication/267969027_Ecient_Competiti on_Testing the 'quiet_life'_of_US_banks_with_adjusted_Lerner_indices/links/54da2d060cf2 970e4e7e1983.pdf (Accessed: 13/04/2018).

Koetter, M., \& Vins, O., (2008). "The Quiet Life Hypothesis in Banking-Evidence from German Savings Banks”, Department of Finance, Goethe University, Working Paper Series: Finance and Accounting No. 190, Frankfurt. https://econpapers.repec.org/paper/frafranaf/190.htm (Accessed: 13/04/2018). 
Koenker, R., \& Bassett, Jr. G., (1978). “Regression quantiles”, Econometrica, 46(1), pp. 3350.

Koenker, R., \& Hallock, F. K., (2001). “Quantile regression”, Journal of Economic Perspectives, 15(4), pp. 143-156.

Kumbhakar, S. C., \& Lovell, C. A. K., (2000). Stochastic Frontier Analysis, Cambridge MA: Cambridge University Press.

Kusi, B. A., Agbloyor, E. K., Ansah-Adu, K., \& Gyeke-Dako, A. (2017). "Bank credit risk and credit information sharing in Africa: Does credit information sharing institutions and context matter?" Research in International Business and Finance, 42(December), pp.11231136.

Kusi, B. A., \& Opoku- Mensah, M. (2018). "Does credit information sharing affect funding cost of banks? Evidence from African banks". International Journal of Finance \& Economics, 23(1), pp. 19- 28.

Lin, C., Ma, Y., Malatesta, P., \& Xuan, Y. (2011). “Ownership structure and the cost of corporate borrowing”. Journal of Financial Economics, 100(1), pp.1-23. 
Love, I., \& Zicchino, L., (2006). “Financial Development and Dynamic Investment Behaviour: Evidence from Panel VAR".The Quarterly Review of Economics and Finance, 46(2), pp. 190-210.

Luoto, J., McIntosh, C., \& Wydick, B. (2007). “Credit information systems in less developed countries: A test with microfinance in Guatemala". Economic Development and Cultural Change, 55(2), pp.313-334.

Manacorda, M., \& Tesei, A., (2016). "Liberation Technology: Mobile Phones and Political Mobilization in Africa", Queen Mary University of London, http://personal.lse.ac.uk/manacorm/liberation_technology.pdf (Accessed: 20/02/2016).

Maudos, J., \& Fernandez de Guevara, J. (2007). "The cost of market power in banking social welfare loss vs. cost efficiency", Journal of Banking and Finance, 31(7), pp. 2103-2125.

Mester, L. J., (1992). “Traditional and nontraditional banking: An information-theoretic approach", Journal of Banking and Finance, 16(3), pp. 545-566.

Minkoua Nzie, J. R., Bidogeza, J. C., \& Ngum, N. A., (2017). “Mobile phone use, transaction costs, and price: Evidence from rural vegetable farmers in Cameroon", Journal of African Business, DOI: 10.1080/15228916.2017.1405704.

https://www.tandfonline.com/doi/abs/10.1080/15228916.2017.1405704 
Mitchell, K., \& Onvural, N. M., (1996). "Economies of scale and scope at large commercial banks: Evidence from the Fourier flexible form”, Journal of Money, Credit and Banking, 28(2), pp. 178-199.

Muazu, I., \& Alagidede, P., (2017). "Financial Development, Growth Volatility and Information Asymmetry in sub-Saharan Africa: Does Law Matter?", South African Journal of Economics, 84(4), pp. 570-588.

Muthinja, M. M., \& Chipeta, C., (2017). “What Drives Financial Innovations in Kenya’s Commercial Banks? An Empirical Study on Firm and Macro-Level Drivers of Branchless Banking”, Journal of African Business, DOI: 10.1080/15228916.2017.1405705. https://www.tandfonline.com/doi/abs/10.1080/15228916.2017.1405705

Ngigi, G., (2013a, July). “CBK puts big banks on the spot over high interest rates”, BUSINESS DAILY, http://www.businessdailyafrica.com/CBK-puts-big-banks-on-the-spotover-high-interest-rates/-/539552/1908098/-/7t6949z/-/index.html (Accessed: 20/06/2016).

Ngigi, G., (2013b, April). "High cost of loans favours big banks over small lenders", BUSINESS DAILY, http://www.businessdailyafrica.com/High-cost-of-loans-favours-bigbanks-over-small-lenders/-/539552/1744902/-/awkd24/-/index.html (Accessed: 20/06/2016).

Noulas, A. G., Ray, S. C., \& Miller, S. M., (1990). "Returns to scale and input substitution for large banks", Journal of Money, Credit and Banking, 22(1), pp. 94-108. 
Okada, K., \& Samreth, S.,(2012). "The effect of foreign aid on corruption: A quantile regression approach", Economic Letters, 11(2), pp. 240-243.

Padilla, A. J., \& Pagano, M., (1997). Endogenous communication among lenders and entrepreneurial initiatives, Review of Financial Studies, 10, pp. 2005-236

Padilla, A. J., \& Pagano, M., (2000). "Sharing default information as a borrower discipline device". European Economic Review, 44 (10), pp. 1951-1980.

Pagano, M., \& Jappelli, T., (1993). "Information sharing in credit markets”, Journal of Finance, 43(5), pp. 1693-1718.

Penard, T., Poussing, N., Yebe, G. Z., \& Ella, P. N., (2012). "Comparing the Determinants of Internet and Cell Phone Use in Africa : Evidence from Gabon ”, Communications \& Strategies, 86(2), pp. 65-83.

Petersen, M.A \& Rajan, R. (1995). "The effect of credit market competition on lending relationship", Quarterly Journal of Economics, 110(2), pp.407-443.

Pierskalla, J. H., \& Hollenbach, F. M., (2013). “Technology and Collective Action: The Effect of Cell Phone Coverage on Political Violence in Africa", American Political Science Review, 107(2), pp. 207-224.

Punt, L., \& Van Rooij, M., (2009). "The Profit-Structure Relationship and Mergers in the European Banking Industry: An Empirical Assessment”, Kredit und Kapital, 36(1), pp. 1-29. 
Pruteanu-Podpiera, A., \& Weill, L., \& Schobert, F., (2008), “Banking Competition and Efficiency: A Micro-Data Analysis on the Czech Banking Industry", Comparative Economics Studies, 50(2), pp. 253-273.

Roodman, D., (2009a). "A Note on the Theme of Too Many Instruments", Oxford Bulletin of Economics and Statistics, 71(1), pp. 135-158.

Roodman, D., (2009b). "How to do xtabond2: An introduction to difference and system GMM in Stata", Stata Journal, 9(1), pp. 86-136.

Rosenberg, M. S., (2005). “The file-drawer problem revisited: a general weighted method for calculating fail-safe numbers in meta-analysis", Evolution, 59(2), pp. 464-468.

Saxegaard, M., (2006), "Excess liquidity and effectiveness of monetary policy: evidence from sub-Saharan Africa", IMF Working Paper No. 06/115, Washington.

http://www.imf.org/external/pubs/ft/wp/2006/wp06115.pdf (Accessed: 13/04/2018).

Schaeck, K., \& Cihak, M., (2008), "How Does Competition Affect Efficiency and Soundness in Banking? New Empirical Evidence”, ECB Working Paper Series No. 932, European Central Bank, Frankfurt.

https://www.ecb.europa.eu/pub/pdf/scpwps/ecbwp932.pdf?8eaa301028741bf824b12e8ab5a4a $\underline{707}$ (Accessed: 13/04/2018). 
Solis, L., \& Maudos, J., (2008), “The Social Costs of Bank Market Power: Evidence from Mexico", Journal of Comparative Economics, 36(3), pp. 467-488.

Snow, B. C., (2009). "Mobile Phone Diffusion and Corruption in Africa", Political Communication, 26(3), pp.333-353.

Stiglitz, J., \&Weiss, A. (1981). “Credit rationing in market with imperfect information”, American Economic Review, 71(3), pp. 393-410.

Tetsushi, H., Yoshiro, T., \& Hirofumi, U., (2014). "Firm Growth and Efficiency in the Banking Industry: A New Test of the Efficient Structure Hypothesis”, Journal of Banking and Finance, 40(March), pp. 143-153.

Tchamyou, S. V., (2017). "The Role of Knowledge Economy in African Business”, Journal of the Knowledge Economy, 8(4), pp. 1189-1228.

Tchamyou, S. V., (2018). "Education, lifelong learning, inequality and financial access: evidence from African countries", Contemporary Social Science, DOI: 10.1080/21582041.2018.1433314. https://www.tandfonline.com/doi/abs/10.1080/21582041.2018.1433314 Tchamyou, S. V., \& Asongu, S. A., (2017). "Information Sharing and Financial Sector Development in Africa”, Journal of African Business, 18(1), pp. 24-49. 
Titko, J., \& Dauylbaev, K., (2015). “Testing the Quiet Life Hypothesis in the Banking Sector", 19th World Multi-Conference on Systemics, Cybernetics and Informatics, WMSCI 2015; Orlando; United States; 12 July 2015 through 15 July 2015; Code 116973. https://www.scopus.com/record/display.uri?eid=2-s2.0-

$\underline{84961196128 \& \text { origin=inward\&txGid=0 }}$ (Accessed: 20/09/2016).

Tobin, J. (1958). "Estimation of relationships for limited dependent variables". Econometrica 26(1), pp. 24-36.

Townsend, R. (1979). “Optimal contracts and competitive markets with costly state verification", Journal of Economic Theory, 21(2), pp. 265-293.

Triki, T., \& Gajigo, O., (2014). "Credit Bureaus and Registries and Access to Finance: New Evidence from 42 African Countries", Journal of African Development, 16(2), pp. 73-101.

Tu, A. H., \& Chen, S., (2000), "Bank Market Structure and Performance in Taiwan Before and After the 1991 Liberalization", Review of Pacific Basin Financial Markets and Policies, 3(4), pp. 475-490.

Tuomi, K., (2011), "The Role of the Investment Climate and Tax Incentives in the Foreign Direct Investment Decision: Evidence from South Africa", Journal of African Business, 12(1), pp. 133-147. 
Vercammen, J. A., (1995). "Credit bureau policy and sustainable reputation effects in credit markets”. Economica, 62(248), pp. 461-478.

Weidmann, J. N., \& Shapiro, N. B., (2015). “Is the Phone Mightier Than the Sword?

Cellphones and Insurgent Violence in Iraq”, International Organisation, 69(2), pp. 247-274.

Weill, L., (2004), "On the Relationship Between Competition and Efficiency in the EU Banking Sectors", Kredit und Kapital, 37(3), pp. 329-352. 